Prepared in cooperation with the National Park Service

\title{
Surficial Geologic Map of Mesa Verde National Park, Montezuma County, Colorado
}
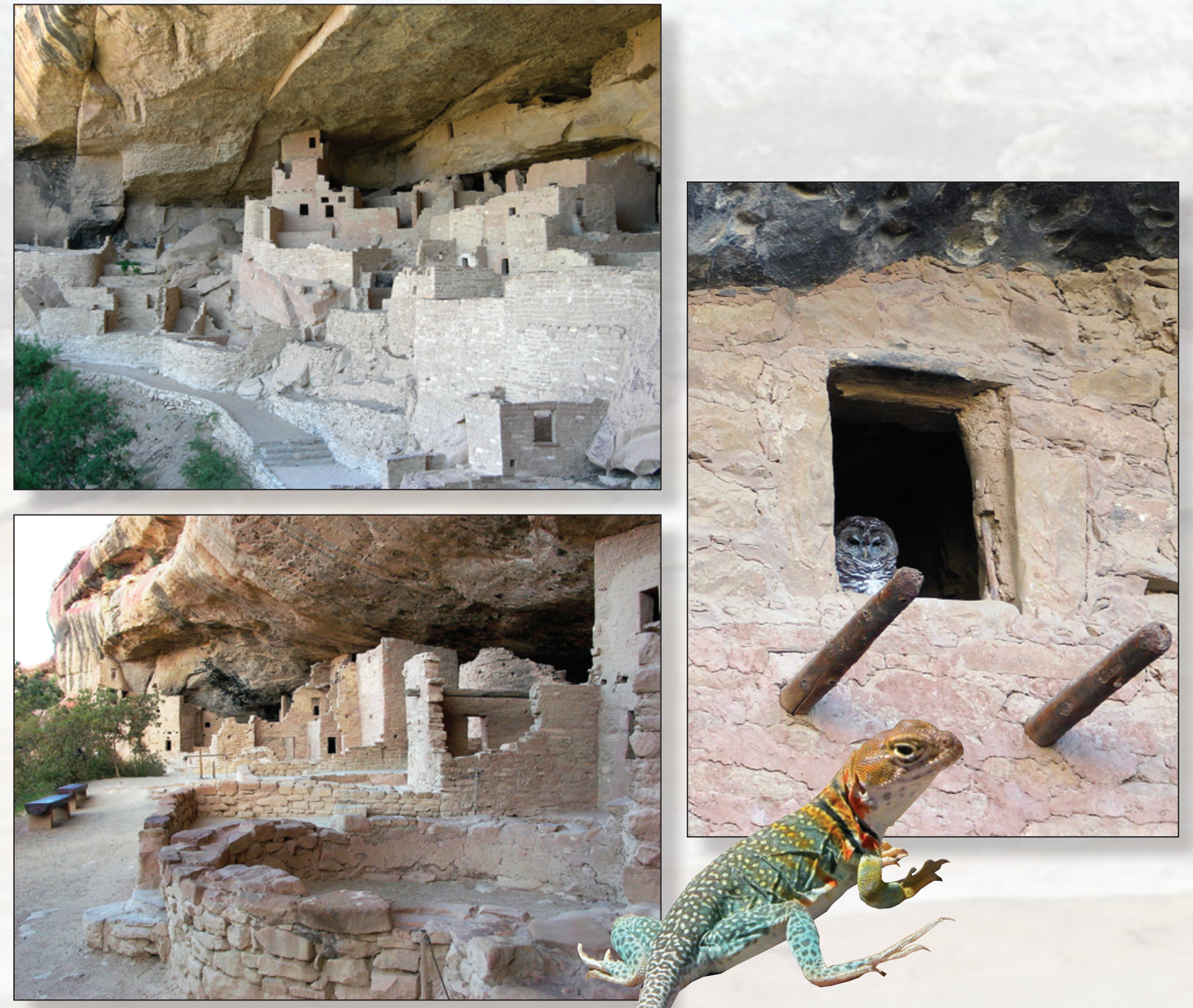

Pamphlet to accompany

Scientific Investigations Map 3224 
Front cover photos. Top left to right. Cliff Palace, photograph taken May 31, 2006, Spotted Owl (courtesy of the National Park Service). Bottom left to right. Spruce Tree House (courtesy of the National Park Service), Collared Lizard (courtesy of the National Park Service). 


\title{
Surficial Geologic Map of Mesa Verde National Park, Montezuma County, Colorado
}

\author{
By Paul E. Carrara
}

Prepared in cooperation with the National Park Service

Scientific Investigations Map 3224 


\section{U.S. Department of the Interior \\ KEN SALAZAR, Secretary \\ U.S. Geological Survey \\ Marcia K. McNutt, Director}

\section{U.S. Geological Survey, Reston, Virginia: 2012}

For more information on the USGS - the Federal source for science about the Earth, its natural and living resources, natural hazards, and the environment, visit http://www.usgs.gov or call 1-888-ASK-USGS.

For an overview of USGS information products, including maps, imagery, and publications, visit http://www.usgs.gov/pubprod

To order this and other USGS information products, visit http://store.usgs.gov

Any use of trade, product, or firm names is for descriptive purposes only and does not imply endorsement by the U.S. Government.

Although this report is in the public domain, permission must be secured from the individual copyright owners to reproduce any copyrighted materials contained within this report.

Suggested citation:

Carrara, P.E., 2012, Surficial geologic map of Mesa Verde National Park, Montezuma County, Colorado:

U.S. Geological Survey Scientific Investigations Map 3224, 22 p. pamphlet, 1 sheet, scale 1:24,000. 


\section{Contents}

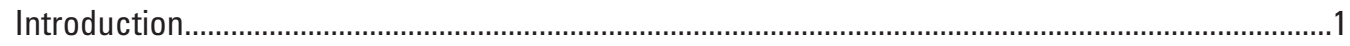

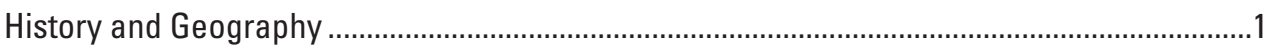

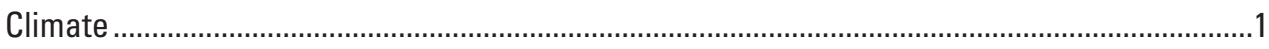

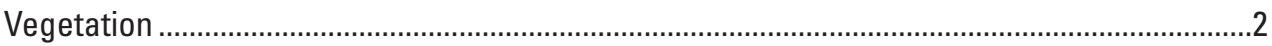

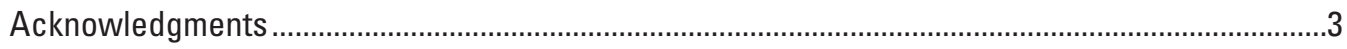

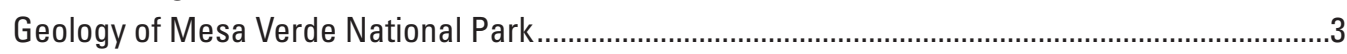

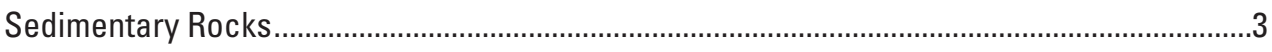

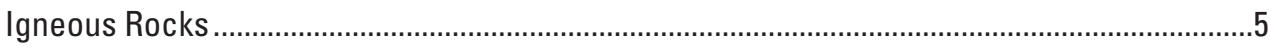

Major Surficial Deposits in Mesa Verde National Park ................................................................5

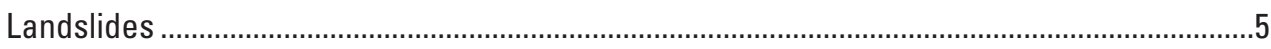

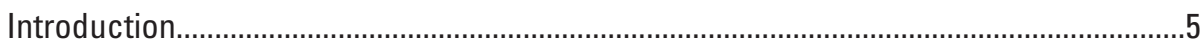

Location of Landslides in Map Area ..............................................................................

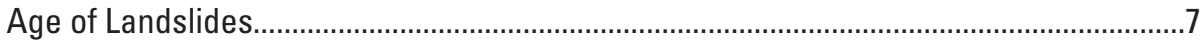

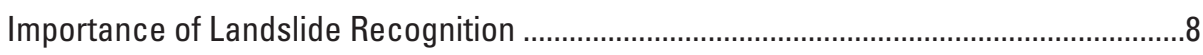

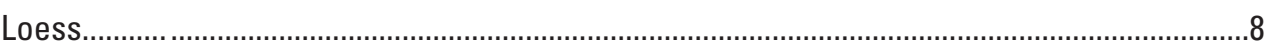

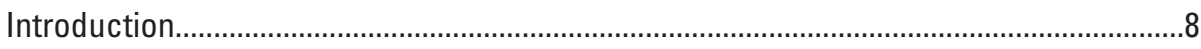

Loess in Mesa Verde National Park ................................................................................9

Age of Loess in Southwestern Colorado ..........................................................................9

Colluvium Derived from Menefee Formation .......................................................................

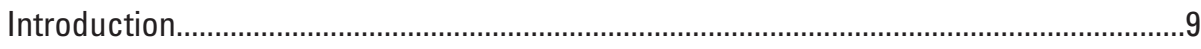

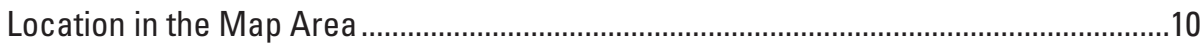

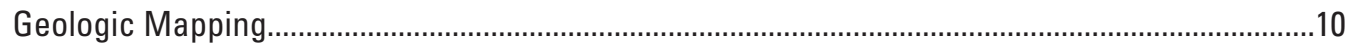

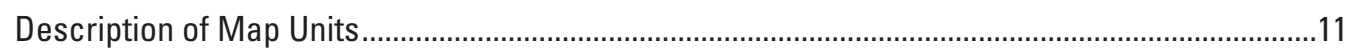

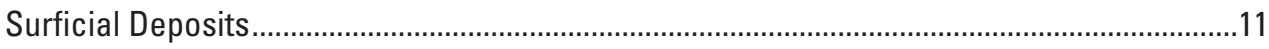

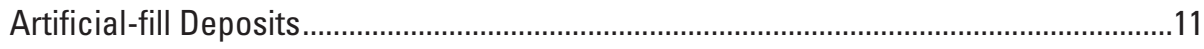

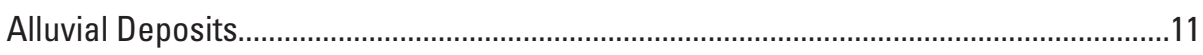

Alluvial and Colluvial Deposits ..........................................................................................12

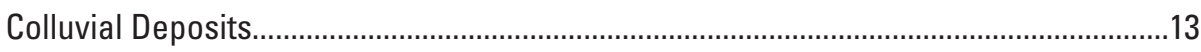

Landslide Deposits .............................................................................................. 14

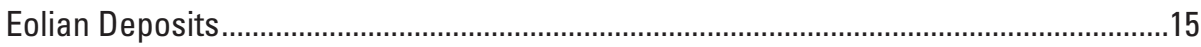

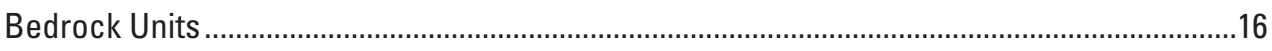

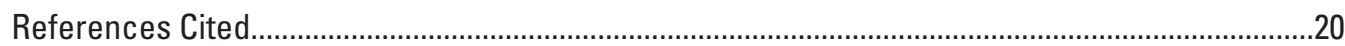

\section{Figures}

1. Index map showing location of Mesa Verde National Park in the southwestern corner of Colorado with place names mentioned in the text. ..............................................2

2. Stratigraphic section of Mesa Verde National Park..........................................................

3. Photograph taken near mile 2 of the entrance road showing two small hills of Mancos Shale capped by Point Lookout Sandstone landslide rubble (Orr)......................6

4. Photograph of large landslide viewed from the Navajo Canyon View Point ....................7

5. Photograph of tilted pinyon pine on the toe of a small landslide in Wickiup Canyon .......8 


\section{Conversion Factors}

Inch/Pound to SI

\begin{tabular}{|c|c|c|}
\hline Multiply & By & To obtain \\
\hline \multicolumn{3}{|c|}{ Length } \\
\hline inch (in.) & 2.54 & centimeter $(\mathrm{cm})$ \\
\hline inch (in.) & 25.4 & millimeter $(\mathrm{mm})$ \\
\hline foot (ft) & 0.3048 & meter $(\mathrm{m})$ \\
\hline mile (mi) & 1.609 & kilometer $(\mathrm{km})$ \\
\hline \multicolumn{3}{|c|}{ Mass } \\
\hline ton & 0.9072 & metric ton \\
\hline
\end{tabular}

SI to Inch/Pound

\begin{tabular}{lll}
\hline \multicolumn{1}{c}{ Multiply } & By & To obtain \\
\hline & Length & \\
\hline centimeter $(\mathrm{cm})$ & 0.3937 & inch (in.) \\
meter $(\mathrm{m})$ & 3.281 & foot (ft) \\
kilometer $(\mathrm{km})$ & 0.6214 & mile (mi) \\
\hline & Mass & tons \\
\hline metric ton & 1.102 & \\
\hline
\end{tabular}

Temperature in degrees Celsius $\left({ }^{\circ} \mathrm{C}\right)$ may be converted to degrees Fahrenheit $\left({ }^{\circ} \mathrm{F}\right)$ as follows:

${ }^{\circ} \mathrm{F}=\left(1.8 x^{\circ} \mathrm{C}\right)+32$

Temperature in degrees Fahrenheit $\left({ }^{\circ} \mathrm{F}\right)$ may be converted to degrees Celsius $\left({ }^{\circ} \mathrm{C}\right)$ as follows:

${ }^{\circ} \mathrm{C}=\left({ }^{\circ} \mathrm{F}-32\right) / 1.8$

Vertical coordinate information is referenced to National Geodetic Vertical Datum of 1929

Horizontal coordinate information is referenced to North American Datum of 1927 (NAD 27)

\section{DIVISION OF QUATERNARY TIME} USED IN THIS REPORT ${ }^{1}$

\begin{tabular}{cccc}
\hline Period or subperiod & Epoch & \multicolumn{1}{c}{ Age } \\
\hline Quaternary & Holocene & & $0-11.7 \mathrm{ka}$ \\
& & late & $11.7-130 \mathrm{ka}$ \\
& Pleistocene & middle & $130-780 \mathrm{ka}$ \\
& & early & $0.780-2.59 \mathrm{my}$ \\
\hline
\end{tabular}

${ }^{1}$ Ages of time boundaries are modified from Bowen and Gibbard (2007) and U.S. Geological Survey (2010). Ages are expressed in ka for kilo-annum (thousand years) and Ma for mega-annum (million years). 


\title{
Surficial Geologic Map of Mesa Verde National Park, Montezuma County, Colorado
}

\author{
By Paul E. Carrara
}

\section{Introduction}

\section{History and Geography}

Mesa Verde National Park in southwestern Colorado (fig. 1), was established in 1906 to preserve and protect the artifacts and dwelling sites, including the famous cliff dwellings, of the Ancestral Puebloan people who lived in the area from about A.D. 550 to A.D. 1300. In 1978, the United Nations designated the park as a World Heritage Site. The geology of the park played a key role in the lives of these ancient people. For example, the approximately 600 cliff dwellings are closely associated with the Cliff House Sandstone of Late Cretaceous age which weathers to form deep alcoves. In addition, the ancient people farmed the thick, red loess (wind-blown dust) on the mesa tops, which because of its particle size distribution has good moisture retention properties. The soil in this loess cover and the seasonal rains of the "Arizona monsoon" allowed these people to grow their crops of corn, beans, and squash on the broad mesa tops.

Today, geology is still an important concern in the Mesa Verde area because the landscape is susceptible to various forms of mass movement (landslides, debris flows, rockfalls), swelling soils, and flash floods that can affect the park's archeological sites and its infrastructure of roads, septic systems, utilities, and building sites.

The map encompasses an area of about $100 \mathrm{mi}^{2}\left(260 \mathrm{~km}^{2}\right)$ and includes all of Mesa Verde National Park, a small part of the Ute Mountain Indian Reservation that borders the park on its southern and western sides (fig. 1), and some Bureau of Land Management and privately owned land to the north and east.

Mesa Verde is essentially a broad gently sloping upland surface, called a cuesta, that dips to the south. It is dissected by a series of generally north-to-south-trending, steep-walled canyons containing ephemeral streams that drain south to the Mancos River (fig. 1). The northern escarpment of the cuesta includes Park Point, the highest point in the park, at an elevation of $8,571 \mathrm{ft}(2,612 \mathrm{~m})$, and drops abruptly more than $2,000 \mathrm{ft}(610 \mathrm{~m})$ into Montezuma Valley where the town of
Cortez is located. This escarpment with its high erosion rate has receded back (south) such that the upper parts of Morefield and Prater Canyons (fig. 1) have been removed by erosion. These canyons are called "beheaded valleys" because the upper parts of their drainages have been removed and their valley floors simply begin abruptly at the escarpment. At the southern edge of the upland surface, approximately 9-10 miles $(14.5-16 \mathrm{~km})$ from the northern escarpment, elevations range from about 6,700 to $6,900 \mathrm{ft}(2,040-2,100 \mathrm{~m})$ and the canyons that have been incised into it are as much as $1,000 \mathrm{ft}(305 \mathrm{~m})$ deep. Along the eastern boundary of the park, the eastern escarpment drops more than 1,500 $\mathrm{ft}(455 \mathrm{~m})$ into the Mancos Valley. Two of the high mesas, Big Mesa and Whites Mesa, have scattered stream-worn pebbles and cobbles on their surfaces, indicating that in the past an ancestral Mancos River flowed across this area. Canyon cutting probably began in the early Pleistocene (2.588-0.78 Ma).

\section{Climate}

The climate of the Mesa Verde National Park region is typical of much of the semiarid southwest. Winters are generally mild with distinct cold snaps, summers are warm, and precipitation is light in most years. The prevailing wind is from the south to southwest. Climate records from February 1922 to December 2010 from a station at an elevation of about $7,100 \mathrm{ft}$ $(2,165 \mathrm{~m})$ on Chapin Mesa, near the park headquarters (fig. 1), indicate a mean January temperature of $29.1^{\circ} \mathrm{F}\left(-1.6^{\circ} \mathrm{C}\right)$ and a mean July temperature of $71.9^{\circ} \mathrm{F}\left(22.2^{\circ} \mathrm{C}\right.$ ) (Western Regional Climate Center, 2011). The lowest temperature on record is $-20^{\circ} \mathrm{F}\left(-29^{\circ} \mathrm{C}\right)$, which occurred on January 13,1963 . The highest temperature on record is $102^{\circ} \mathrm{F}\left(39^{\circ} \mathrm{C}\right)$, which occurred on July 24, 1936. Mean annual precipitation in the park is 18.15 in. $(46 \mathrm{~cm})$ and is fairly evenly distributed throughout the year with 1.5 to 2 in. (3.8 to $5.1 \mathrm{~cm}$ ) falling in most months except May $(1.07 \mathrm{in} ., 2.7 \mathrm{~cm})$ and June $(0.61 \mathrm{in} ., 1.5 \mathrm{~cm})$ when a dry period commonly occurs. After this dry period, the summer precipitation is usually in the form of intense thunderstorms often accompanied by hail. The thunderstorms occur about 40 days each year, mainly in July and August. Average annual snowfall totals 81 in. $(206 \mathrm{~cm}$ ) (Western Regional Climate Center, 2011). 


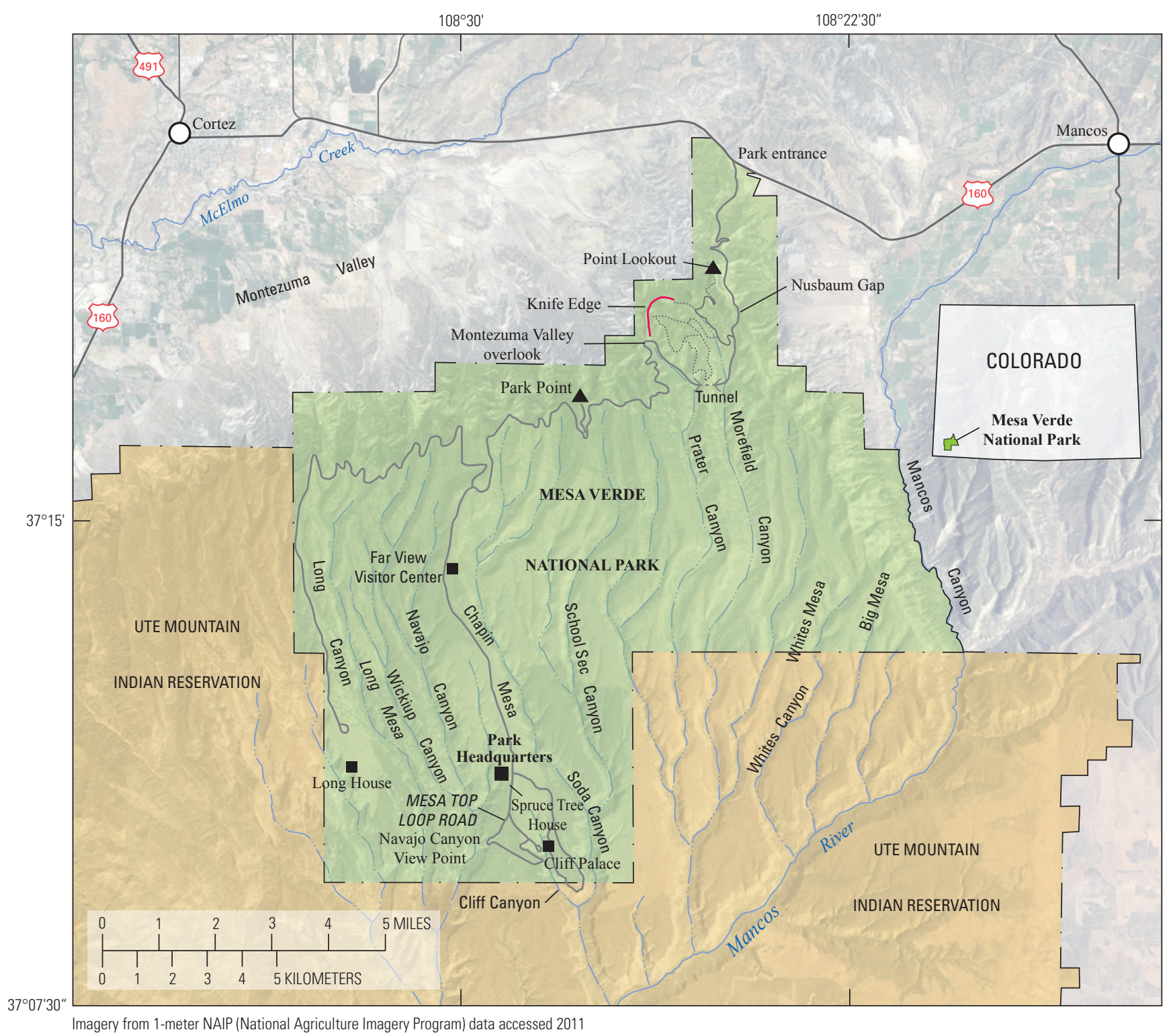

Figure 1. Index map showing location of Mesa Verde National Park in the southwestern corner of Colorado with place names mentioned in the text.

\section{Vegetation}

Several vegetation zones are present in the Mesa Verde National Park area because of its semiarid climate, moderate altitude, and relief. The two most extensive vegetation types are the pinyon-juniper forests (Pinus edulis and Juniperus osteosperma), and Petran chaparral or montane shrubland of Gambel oak (Quercus gambellii) and Utah serviceberry (Amelanchier utahensis) (Floyd and others, 2000). Pinyon pine and Utah juniper dominate the lower elevations, from 5,700 to about $7,400 \mathrm{ft}$ (1,735 to about 2,255 m), of the mesas and canyon slopes in the southern area of the park and the lower northern and eastern sides of the escarpment. Douglas fir (Pseudotsuga menziesii) and ponderosa pines (Pinus ponderosa) are also found at these low elevations in well-shaded canyons. At the lower elevational boundary, the pinyons and junipers are small and widely spaced; with increasing elevation, they become larger and more closely spaced, forming dense woodlands. The ground under the pinyon-juniper forests is commonly bare and rocky, but may support a sparse cover of shrubs, such as big sagebrush (Artemisia tridentate) and bitterbrush (Purshia tridentat), and various grasses and forbs. Above about 7,400 ft $(2,255 \mathrm{~m})$, in the northern park area, the pinyon-juniper forest gives way to a chaparral dominated by Gambel oak and Utah serviceberry with mixed conifers, including ponderosa pine and Douglas fir. These two vegetation zones have similar floristic composition, but differ in appearance and species abundance. Hence, the chaparral may contain scattered pinyon or juniper trees, and many of the chaparral's shrub species also grow in the understory of the pinyon-juniper woodlands (Floyd and others, 2000). 


\section{Acknowledgments}

This research was supported by the National Cooperative Geologic Mapping Program of the U.S. Geological Survey and is a contribution to the "Geology of the Parks and Federal Lands of the Southwest" project. The author was visited and (or) assisted in the field at various times by Mary L. Gillam, consulting geologist; Diana E. Anderson, R. Scott Anderson, and Taylor J. Joyal, Northern Arizona University; Fumiyasu Arakawa, Crow Canyon Archaeological Center; Robert W. Blair Jr., Fort Lewis College; Kimberlee M. Gerhardt, consulting geologist; David A. Gonzales, Fort Lewis College; R. Mark Leckie, University of Massachusetts; and the following U. S. Geological Survey personnel: Harlan Goldstein, Marith C. Reheis, Richard L. Reynolds, and James C. Yount; their ideas and suggestions were greatly appreciated. Discussions with Marilyn Coyler and Linda Martin, National Park Service; Mary O. Griffitts, consulting geologist; Douglas K. Ramsey, National Resources Conservation Service; and Daniel R. Muhs, and Michael P. Pantea, U.S. Geological Survey, also added greatly to this manuscript. Jim Messerich and Paco Van Sistine, U.S. Geological Survey, provided invaluable support in the Photogrammetric and GIS labs, respectively. I gratefully acknowledge the helpful comments of David Lidke and Richard F. Madole, U.S. Geological Survey, who kindly reviewed earlier drafts of this manuscript. I also wish to thank the National Park Service, Mesa Verde National Park, for various logistical help and specifically George San Miguel, Natural Resource Officer, and Bruce Heise, National Park Service, for supporting and encouraging this study.

\section{Geology of Mesa Verde National Park}

\section{Sedimentary Rocks}

Four geologic formations (fig. 2), all Late Cretaceous (99.6-65.5 Ma) in age and dipping gently to the south, are exposed in the Mesa Verde area (Wanek, 1954, 1959; Haynes and others, 1972; Griffitts, 1990; Condon, 1991; Leckie and others, 1997). From oldest to youngest these are the Mancos Shale, Point Lookout Sandstone, Menefee Formation and Cliff House Sandstone. The upper three formations comprise the Mesaverde Group (fig. 2), a name that has been applied to sandstones and coal-bearing units of Upper Cretaceous age over large areas of the Rocky Mountains and the Southwest (Wanek, 1959).

The lowest formation exposed in Mesa Verde National Park is the Mancos Shale (fig. 2), a thick sequence of gray to black fissile shale containing siltstone, and fine-grained sandstone beds that are generally less than a foot thick $(30 \mathrm{~cm})$, deposited in a deep-water marine environment in the Late Cretaceous sea (Leckie and others, 1997). Near the park entrance, in the section below Point Lookout (fig. 1), Wanek (1959) measured about 2,000 ft (610 m) of Mancos Shale but excluded the transitional zone with the overlying Point Lookout Sandstone. Leckie and others (1997) measured a total Mancos Shale thickness of about $2,240 \mathrm{ft}(685 \mathrm{~m})$ in this same area. This formation is prone to landsliding where exposed on steep slopes, such as those along the northern and eastern escarpments.

Overlying and gradational with the Mancos Shale is the Point Lookout Sandstone of the Mesaverde Group (fig. 2). The Point Lookout Sandstone was deposited as barrier beaches and near-shore sands (Griffitts, 1990) as the Late Cretaceous sea retreated to the south. The lower part of this formation consists of interbedded yellowish-gray and light-brown, fine-grained, cross-bedded sandstone and olive-gray to gray, sandy, fossiliferous shale. Sections along the northern escarpment measured by Wanek (1959) indicate its thickness ranges between 80 and $125 \mathrm{ft}(25$ and $38 \mathrm{~m})$ in the Mesa Verde area. The upper part consists of thick to massive beds of yellowish-gray, paleorange, and light-gray, fine- to medium-grained, cross-bedded sandstone. Again, sections in the Mesa Verde area, along the northern escarpment measured by Wanek (1959) indicate a thickness of about $250 \mathrm{ft}(75 \mathrm{~m})$. The formation forms much of the cap rock in the northern park area and is generally stable, but is prone to rockfall where the underlying Mancos Shale has undercut it.

The Menefee Formation conformably overlies the Point Lookout Sandstone (fig. 2) and consists of gray to grayishorange lenticular, cross-bedded sandstone and gray to brownish-gray and black carbonaceous shale, coal beds, and bentonitic clay beds. This formation was deposited in a broad coastal plain environment (Condon, 1991), indicating further retreat of the Late Cretaceous sea. In the Mesa Verde area, the Menefee Formation is about 350-400 ft (105-120 m) thick (Wanek, 1959) and forms broad slopes, usually with a thick overlying colluvial cover, within many of the park's canyons. This colluvial cover is prone to failure on steep slopes and forms many of the landslides shown on the accompanying map. Because there are few areas in the park where one can actually see the Menefee Formation because of the thick colluvial cover, the colluvial cover is mapped as a separate map unit (Qcmf).

The Cliff House Sandstone overlies the Menefee Formation (fig. 2). This sandstone consists of a grayish-orange to pale-yellow, fine-grained, thick-bedded sandstone deposited in a shallow near-shore marine environment (Wanek, 1959), indicating a northward transgression of the Late Cretaceous sea. In the southern part of the park, the formation commonly consists of two massive, cliff-forming sandstone beds, each more than $100 \mathrm{ft}(30 \mathrm{~m})$ thick, separated by a thin shale unit (Griffitts, 1990). A maximum thickness of about $400 \mathrm{ft}$ (120 m) is present in the Echo Cliff section of Navajo Canyon (Wanek, 1959) and can be viewed from the Navajo Canyon View Point (fig. 1). The upper sandstone bed weathers to form deep alcoves in which many of the cliff dwellings have been built (Wanek, 1959; Griffitts, 1990). Generally, this formation is stable, although rockfalls sometimes occur from the ceilings of the alcoves and along the massive cliff walls. The Cliff House Sandstone intertongues at its base with the underlying Menefee Formation. 
Stratigraphic Units within Mesa Verde National Park

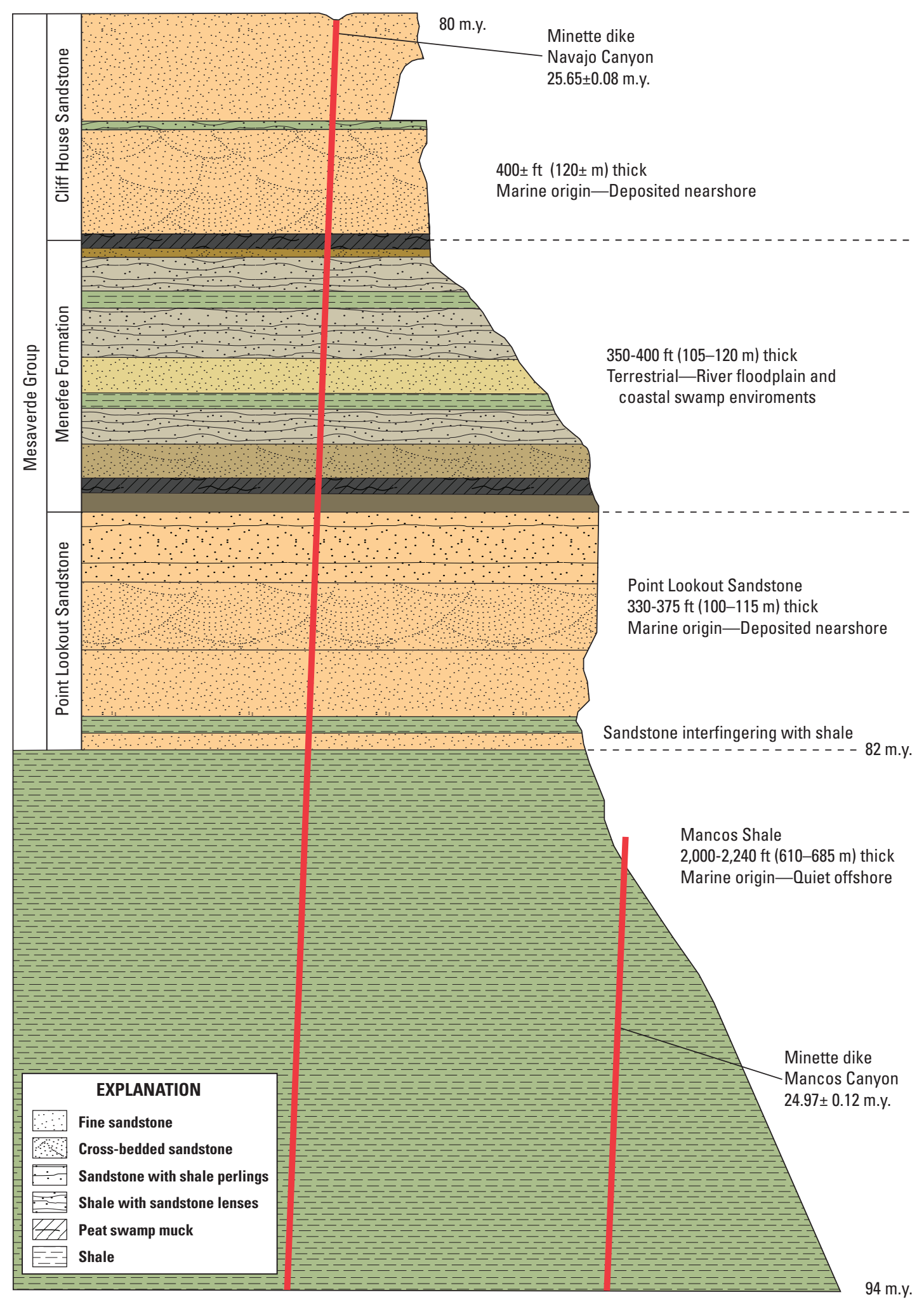

Figure 2. Stratigraphic section of Mesa Verde National Park (after Griffitts, 1990). Ages given are from Cobban and others (2006), W.A. Cobban, USGS, personal commun. (2007), and Peters (2011a, 2011b). 


\section{Igneous Rocks}

At several locations in the Mesa Verde area dikes and diatremes of minette rock are exposed (Wanek, 1954, 1959; Condon, 1991; Griffitts, 1999). Minette is a potassic (K) mica lamprophyre (ultrapotassic igneous rock of deep origins), commonly greenish-gray to black in color. Basically, minette is a phlogopite-rich, potassic basalt (D.A. Gonzales, Fort Lewis College, personal commun., 2010). The rocks exposed in the study area are characterized by an aphanitic (very fine-grained) groundmass of minerals dominated by sanidine (bladed to poikilitic), diopside, phlogopite, and minor apatite. Phenocrysts (relatively large, conspicuous crystals) in these rocks include the minerals phlogopite, diopside, and less commonly olivine (Semken, 2003; Gonzales and others, 2010), that comprise less than 10 percent to more than 50 percent of the rock (D.A. Gonzales, Fort Lewis College, written commun., 2011). Minette forms by cooling from a potassic-rich lamprophyre melt. The geochemical signatures indicate partial melting of lithospheric mantle (Gonzales and others, 2010). Dikes are well exposed in the soft Menefee Formation and Mancos Shale, and form gullies where they have intruded into the more resistant Cliff House and Point Lookout Sandstones. In Navajo Canyon (fig. 1), there is a well-exposed vertical dike that is about $10-15 \mathrm{ft}(3-5 \mathrm{~m})$ wide, and stands about $30-45 \mathrm{ft}$ (9-14 $\mathrm{m}$ ) above the surrounding Menefee Formation, which it intrudes. In Mancos Canyon (fig. 1) a near-vertical minette dike intrudes the Mancos Shale and has a maximum thickness of about $6 \mathrm{ft}(2 \mathrm{~m})$ and at its southern end stands about $15 \mathrm{ft}$ ( $4.6 \mathrm{~m}$ ) above the Mancos Shale. In some locations, calcite- and fluorite-rich breccias occur in minette dikes and diatremes and extend into adjacent country rock. These vein-breccia zones are interpreted as dominantly late-stage volatiles associated with mafic magmas (D.A. Gonzales, Fort Lewis College, written commun., 2011). Samples from two minette dikes within the park yielded ${ }^{40} \mathrm{Ar} /{ }^{39} \mathrm{Ar}$ ages of about 25 million years (Peters, 2011a and 2011b) indicating that they are of Oligocene age (33.9-23.03 Ma; U.S. Geological Survey, 2010).

\section{Major Surficial Deposits in Mesa Verde National Park}

Three major surficial geologic units dominate the Mesa Verde area: landslides, loess, and the thick colluvial cover derived from the Menefee Formation.

\section{Landslides}

\section{Introduction}

Landslide is a general term for landforms produced by a wide variety of gravity-driven mass movements, including various types of flows, slides, topples and falls, and combinations thereof produced by the slow to rapid downslope transport of surficial materials or bedrock. Landslide movement takes place on an inclined failure surface that separates the displaced material above from intact substrata below.

Landslides are a dominant surficial feature in the Mesa Verde area, comprising about $8.8 \mathrm{mi}^{2}\left(23 \mathrm{~km}^{2}\right)$, or about 9 percent of the map area. More than 150 landslides, most previously unrecognized and unmapped, have been identified in the map area. These landslides range in size from small $\left(0.01 \mathrm{mi}^{2}-0.026 \mathrm{~km}^{2}\right)$ debris flows (Qdf), earthflows (Qef), and rockfalls (Qrf), to large (greater than $0.50 \mathrm{mi}^{2}-1.30 \mathrm{~km}^{2}$ ) rock avalanches (Qrr), and translational-rotational landslides (Qtr) (Varnes, 1978). Landslide morphology and topographic relief between the head and toe suggest that some of the larger landslide deposits may be more than $100 \mathrm{ft}(30 \mathrm{~m})$ thick.

Physical characteristics common to landslides that aided in their identification included: (1) headwall scarps, (2) hummocky topography, including closed depressions, (3) bulging landslide toes, (4) deflection of ephemeral stream channels by landslide toes, (5) bedrock blocks with anomalous dips and strikes, (6) displaced masses of geologic units downslope from their sources, and (7) vegetation scarring, especially along the northern escarpment. Low sun-angle in the early morning and late afternoon enhanced the visibility of the subdued topography of many older landslide deposits and was a useful aid to their identification in the field.

\section{Location of Landslides in the Map Area}

Within the Mesa Verde National Park area many landslides occur in the Menefee Formation and Mancos Shale. Landslides are present both along the northern and eastern escarpments and within the canyons of the park. Along the steep slopes of the northern and eastern escarpments both the Menefee Formation and Mancos Shale commonly fail as debris flows (Qdf), and the Mancos Shale also fails as translational or rotational landslides (Qtr), such as the large landslide near the head of Morefield Canyon. On the escarpments, many of the slopes underlain by Mancos Shale are bare of vegetation indicating very high rates of erosion and ongoing masswasting processes.

Prior to 1957, the entrance road into Mesa Verde National Park traversed the steep Mancos Shale slopes along the northern escarpment between the heads of Morefield and Prater Canyons. This 1.5 -mile $(2.4 \mathrm{~km})$ section of road was known as the "Knife Edge" (fig. 1). Landslide movement in the eastern part of the Knife Edge consisted of mostly large blocks of weathered shale which disintegrated into debris slides and, in wet weather, into small mudflows as they moved downslope (Varnes, 1949). Movement in the western part was mainly by rockfall and, to a lesser extent, rockslides (Varnes, 1949). This section of road was eventually considered too treacherous to maintain by the National Park Service (Martin, 2005). In 1957 a 1,400-ft $(427 \mathrm{~m})$ tunnel was constructed between Morefield and Prater Canyons (Dobrovolny and others, 1954; Bohman, 1958) resulting in the abandonment of the Knife Edge section. 
From the head of Morefield Canyon one can walk a section of this old road along the park's Knife Edge Trail. From the Montezuma Valley Overlook (fig. 1), at the head of Prater Canyon, visitors can view the remains of this road as it traversed the steep Mancos Shale slope below the Knife Edge. By bypassing and abandoning the Knife Edge section of road, the present entrance road traverses only about 1.6 miles $(2.6 \mathrm{~km})$ of steep Mancos Shale slopes along the eastern face of Point Lookout.

Mass-wasting of the underlying Mancos Shale along the northern and eastern escarpments also undercuts the overlying Point Lookout Sandstone, which then fails as large rockfalls, rock avalanches, and (or) debris flows. This rubbly sandstone debris buries the shale, protecting it from erosion. Evidence of this process can be observed along the first few kilometers of the park entrance road where several small hills and ridges of Mancos Shale are capped by a jumble of sandstone blocks derived from the Point Lookout Sandstone (fig. 3). These hills and ridges stand above adjacent areas because the sandstone rubble acted as a protective cap that shielded the underlying Mancos Shale from erosion.
The Menefee Formation and the colluvial deposits (Qcmf) derived from this formation, are prone to failure on steep slopes and are the sources of many of the large translational or rotational landslides (Qtr) in the park's canyons. One of these large landslides can be observed from Navajo Canyon View Point (fig. 4). Here, the landslide forced the ephemeral stream channel to the eastern side of the canyon, temporarily damming the canyon and forming a flat-valley floor underlain by alluvium upvalley from the landslide. On the northern and eastern escarpments, detritus from the Menefee Formation commonly fails as debris flows (Qdf). Recent debris flows on these rims are highlighted by scarring of the slope vegetation.

Much of the road between Montezuma Valley Overlook and the Park Point (fig. 1) turnoff is on the Menefee Formation. Parts of this section of road had to be rerouted because the soft organic-rich shales and thin-bedded, brittle coal layers of the formation are too unstable to allow the road to be maintained safely (Griffitts, 1990).

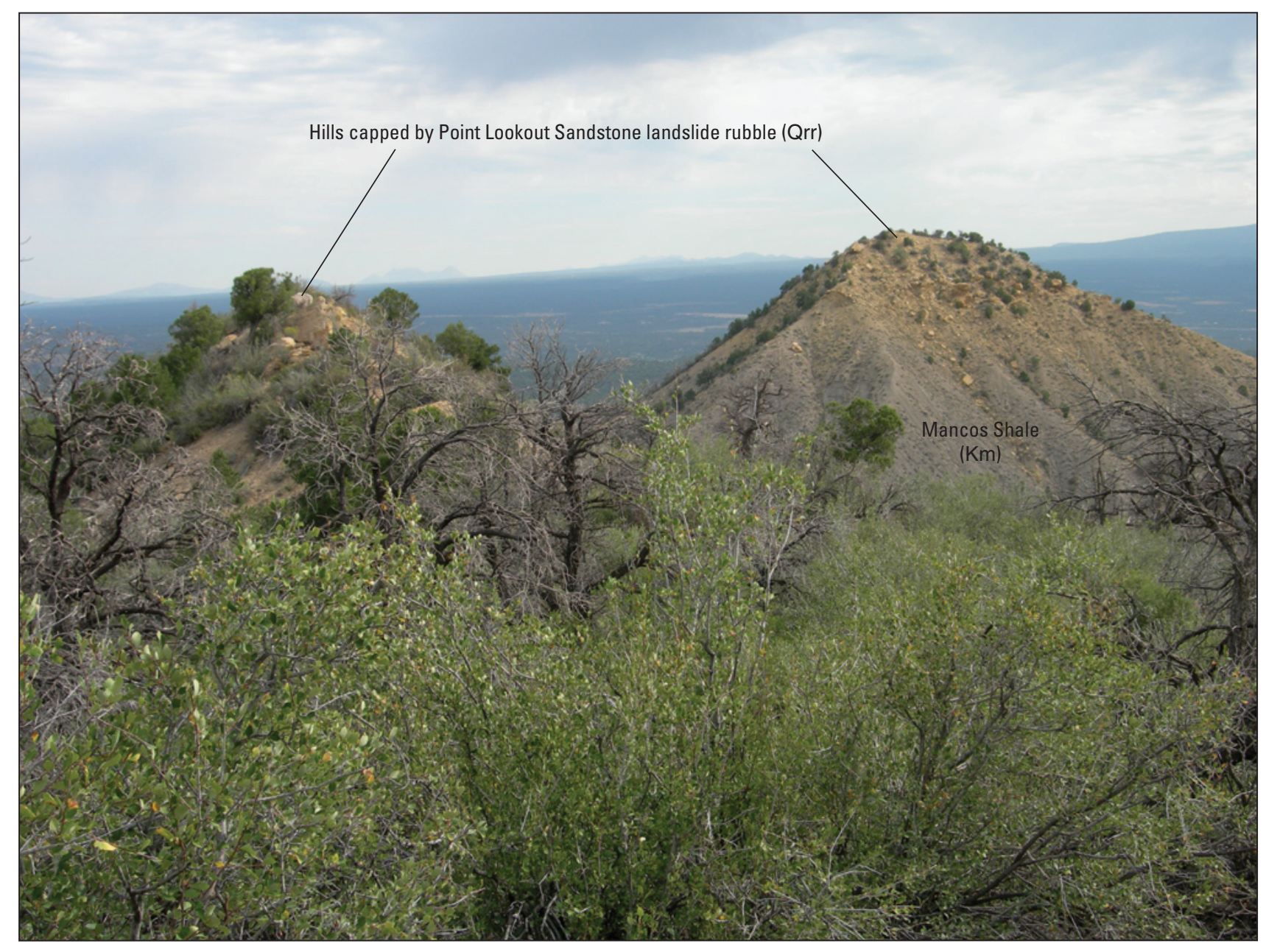

Figure 3. Photograph taken near mile 2 of the entrance road showing two small hills of Mancos Shale capped by Point Lookout Sandstone landslide rubble (Qrr). Photograph taken Aug. 26, 2007. 


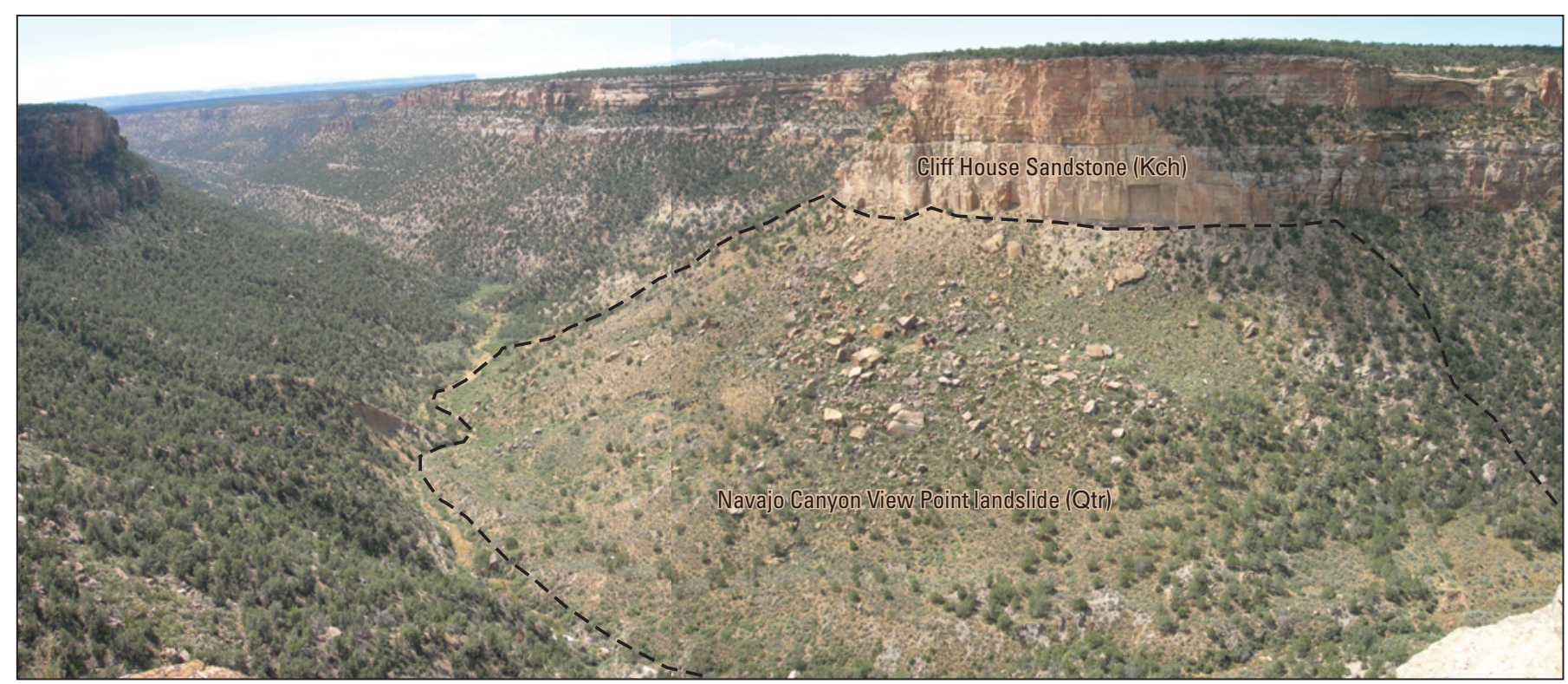

Figure 4. Photograph of large landslide viewed from the Navajo Canyon View Point (fig. 1). Note that the landslide has forced the ephemeral-stream channel to the eastern side of the canyon. In addition, the landslide temporarily dammed the canyon, forming a flat valley floor underlain by alluvium upstream (beyond the photo to the right). Photograph taken Aug. 28, 2005.

\section{Age of Landslides}

Landsliding in the Mesa Verde area was probably more active during the Pleistocene Epoch, which ended about 11,700 years ago, when the climate in this region was at times wetter and cooler than present. In addition, during these times, because of the wetter conditions, canyon incision probably occurred at a faster rate than at present. A deposit (Qrr) on a hill near the entrance station to Mesa Verde National Park demonstrates an ancient age for some of the landslide deposits shown on this map. The hill, at an elevation of 7,388 ft (2,252 m), is approximately $300 \mathrm{ft}(91 \mathrm{~m})$ above the surrounding terrain and is capped by about $30 \mathrm{ft}(9 \mathrm{~m})$ of Point Lookout Sandstone rubble. The rubble consists of sand to boulders as large as $10 \mathrm{ft}$ $(3 \mathrm{~m})$ in intermediate diameter and was emplaced by a large rockfall, rock avalanche, or debris flow originating from the Point Lookout Sandstone. That this hill is now $300 \mathrm{ft}$ (91 m) above the surrounding terrain of Mancos Shale and the nearest outcrop of Point Lookout Sandstone is at Point Lookout, about 1.5 miles $(2.4 \mathrm{~km})$ to the south, suggests that an extended period of erosion, possibly on the order of several hundreds of thousands of years, has occurred since the deposition of this deposit.

However, landsliding is still an ongoing process in Mesa Verde National Park. Because the park has only one entrance road which traverses a steep slope of Mancos Shale along the eastern side of Point Lookout, a landslide along this slope has the potential to trap thousands of visitors inside the park. Plazak (1989) documented a history of landslides along this section of road that he was able to compile from many different sources. He cautions the reader that this may be only a partial list as records were incomplete and often vague in their location description.

One of the more notable landslides Plazak (1989) was able to document occurred after an exceedingly wet autumn in 1978. During the spring of 1979 , a series of landslide movements along the east side of Point Lookout closed the entrance road for more than a month (Plazak, 1989; Smith, 2002). The first landslide occurred on April 28th, when 100,000 $\mathrm{ft}^{3}$ $\left(2,830 \mathrm{~m}^{3}\right)$ of material slumped onto a $200-\mathrm{ft}(61 \mathrm{~m})$ section of the road. Before this first landslide could be cleared from the road, a second landslide on April 30th deposited about $680,000 \mathrm{ft}^{3}\left(19,250 \mathrm{~m}^{3}\right)$ of material onto the road north of the first slide (Plazak, 1989). In addition, on May 27th, a $250-\mathrm{ft}$ $(76 \mathrm{~m})$ section south of the two previous landslides involving one lane of the road moved downslope, further delaying the reopening of Mesa Verde National Park (Plazak, 1989). Over the years, millions of dollars have been spent keeping the park's road system open (G. San Miguel, National Park Service, written commun., 2005).

Further evidence of ongoing landslide activity is indicated by tilted pinyon and juniper trees on a small landslide (fig. 5) in the Menefee Formation in Wickiup Canyon (fig. 1) in the southwestern part of the park. The tilted trees indicate landslide movement during the lifetime of the trees. Tree-ring analysis of increment cores taken from several of the tilted trees indicated the landslide occurred in 1986. In addition, many small landslides in Mesa Verde National Park were recorded between 1974 and 2006 (Marilyn Coyler, National Park Service, written commun., 2006). Other recent landslides on the northern and eastern escarpments are indicated by fresh scars in vegetation. 


\section{Importance of Landslide Recognition}

Many of the landslides depicted on this map are probably stable because they date to the Pleistocene and hence formed under a different climatic regime. However, the recognition of these landslides is important because natural and humaninduced factors can alter stability. Reduction of lateral support (for example, by excavations or roadcuts), removal of vegetation (for example, by fire or development), or an increase in pore-water pressure caused by heavy rains or snowmelt may result in a decrease in internal shear strength and hence, in the reactivation of the landslide or parts of landslide.

\section{Loess}

\section{Introduction}

Loess is an accumulation of wind-blown silt and lesser amounts of fine sand and clay. Commonly massive and in places calcareous, it is usually homogeneous and highly porous. Loess deposits form a "blanket" that covers large areas obscuring the underlying bedrock. In the Midwestern United
States, loess deposits cover more than 1.740 million $\mathrm{mi}^{2}$ $\left(4.5\right.$ million $\left.\mathrm{km}^{2}\right)$. The youngest loess (Peoria Loess) in this area is more than $130 \mathrm{ft}(40 \mathrm{~m})$ thick in places (Bettis and others, 2003). In many areas loess develops into highly rich soils and forms some of the most agriculturally productive terrain in the world.

In an area of southwestern Colorado that includes Mesa Verde National Park, soil surveys indicate that reddish-colored eolian deposits blanket an area of more than $3,750 \mathrm{mi}^{2}$ $\left(9,700 \mathrm{~km}^{2}\right)$ (Price and others, 1988). Arrhenius and Bonatti (1965) referred to these reddish-colored deposits as the "Mesa Verde Loess". The average thickness of the eolian deposits in this area is uncertain, but Price and others (1988) suggested that some of the deposits may be more than $6 \mathrm{ft}(2 \mathrm{~m})$ thick, although much of it may not exceed $3 \mathrm{ft}(1 \mathrm{~m})$ in thickness. Along a southwest-to-northeast transect from the ColoradoUtah border to the Dolores River, the silt content in eolian deposits ranged from about 22 to 56 percent (Price and others, 1988, their table 2). Furthermore, with increasing distance northeast from the Colorado-Utah border (and hence the San Juan River) the silt content increased, whereas the sand content decreased, indicating that for the Mesa Verde area the direction of the winds that deposited the eolian material was from the south-southwest (Price and others, 1988). Possible

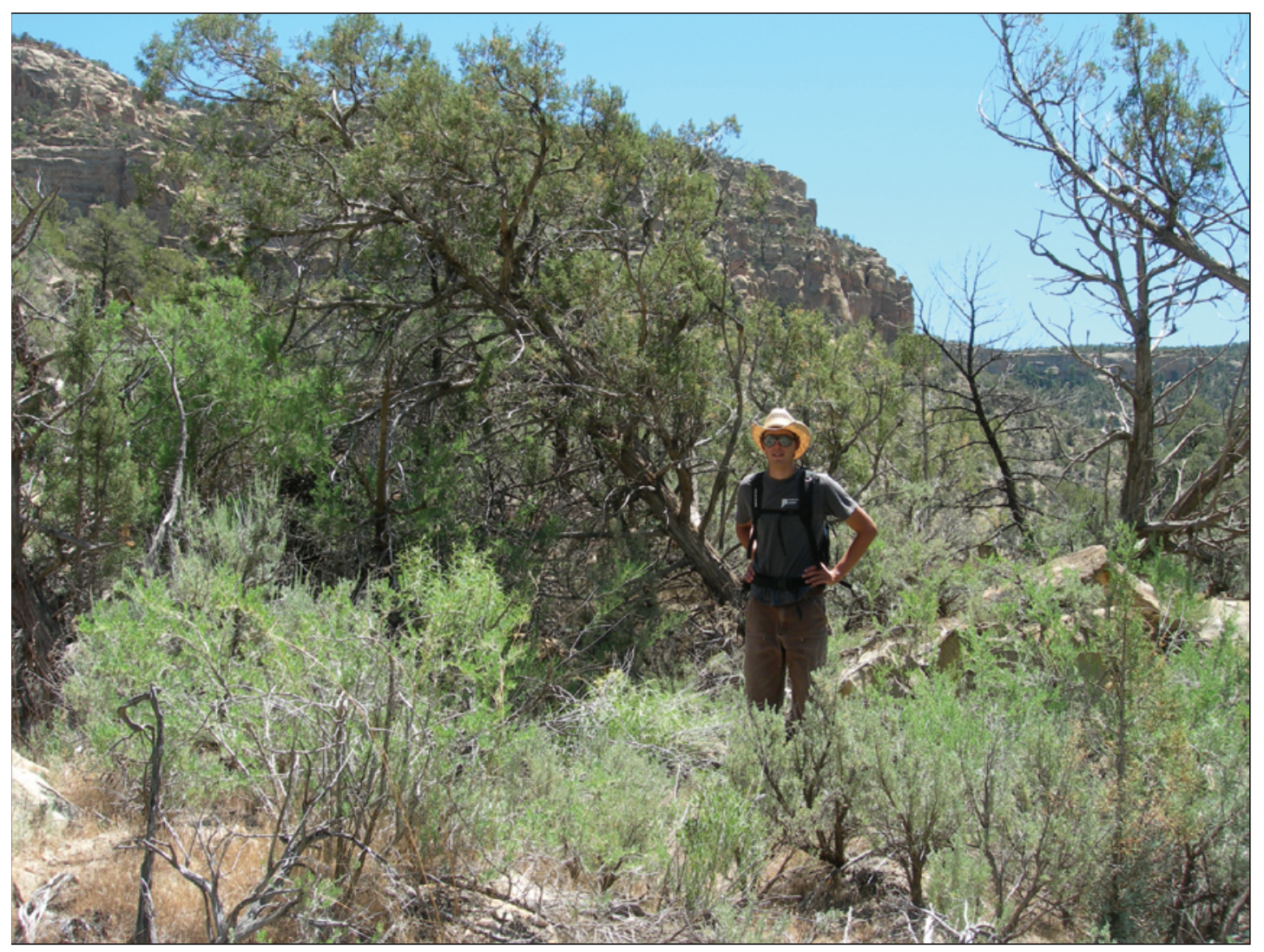

Figure 5. Photograph of tilted pinyon pine on the toe of a small landslide in Wickiup Canyon (fig. 1). The tilted tree indicates landslide movement during its lifetime. Tree-ring analysis of increment cores taken from several trees on this landslide indicate movement occurred in 1986. Photograph taken June 12, 2006. 
sources for the eolian deposits include; (1) the large areas of sparse vegetation to the southwest containing reddish-colored sedimentary rocks, (2) alluvium of the San Juan River, also to the southwest, that contains abundant reddish-colored rocks in its drainage basin, and (3) a combination of the above possible sources (Price and others, 1988).

\section{Loess in Mesa Verde National Park}

In Mesa Verde National Park large areas of the mesas are blanketed by loess (Ramsey, 2003) such that loess comprises about $6.7 \mathrm{mi}^{2}\left(17.5 \mathrm{~km}^{2}\right)$ or about 7 percent of the map area. Arrhenius and Bonatti (1965) inspected two man-made exposures of loess within the park that have since been filled in. One of the exposures, referred to as the "new garbage pit," was about $1.85 \mathrm{mi}(3 \mathrm{~km})$ south of the park's headquarters near the southern boundary of the park on Chapin Mesa (fig. 1). Here the loess was about $9 \mathrm{ft}(2.75 \mathrm{~m})$ in thickness. At this exposure, upper and lower loess units were distinguished. In the upper loess, which was about $3.5 \mathrm{ft}(1.1 \mathrm{~m})$ thick, two loess units were recognized (Loess 1 and 2). The lower loess (Loess 3), which contains more coarse material, indicating that it was transported by higher velocity winds than the overlying loess ( 1 and 2$)$, is about $5.5 \mathrm{ft}(1.70 \mathrm{~m})$ thick. This lower loess had the most marked soil development including a welldefined stage III morphology in a calcic soil that is about $2.5 \mathrm{ft}$ $(75 \mathrm{~cm})$ thick and referred to as the "basal caliche" by Arrhenius and Bonatti (1965). Analysis of the calcic soil indicated a concentration of 54 percent calcium carbonate, corresponding to an almost complete filling of the pore spaces between grains (Arrhenius and Bonatti, 1965). Although the "new garbage pit" exposure no longer exists, the layer containing stage III carbonate morphology can be viewed at some of the pithouse and kiva exhibits along the Mesa Top Loop Road on Chapin Mesa where it is easily recognized as a prominent white layer $1.5-3 \mathrm{ft}(0.5-1 \mathrm{~m})$ below the surface.

The other section, referred to as the "juniper section," was about $1 \mathrm{mi}(1.6 \mathrm{~km})$ northeast of the park's headquarters. Here the loess was only about $2.5 \mathrm{ft}(0.75 \mathrm{~m})$ thick, and two loess units were identified: zones 1 and 2 (Arrhenius and Bonatti, 1965). Again, the lower loess (zone 2) contained more coarse material than the upper loess (zone 1). Based on this difference in grain-size distribution, zone 1 at the juniper section was correlated with loess 1 and 2 at the "new garbage pit," and zone 2 at the juniper section was correlated with loess 3 at the "new garbage pit" (Arrhenius and Bonatti, 1965).

\section{Age of Loess in Southwestern Colorado}

Evidence suggests that loess deposits in southwestern Colorado were deposited by a series of eolian events during the Quaternary. Hunt (1956, p. 38) thought that the loess deposits were pre-Wisconsin in age (older than about 75,000 years). Arrhenius and Bonatti (1965) concluded that the earliest loess at the "new garbage pit" exposure (loess 3 ) was probably
pre-Wisconsin, possibly Sangamon in age (between about 125,000 and 75,000 years ago). Furthermore, the presence of a stage III carbonate horizon in loess 3 suggests that it is middle Pleistocene in age (780,000 to 130,000 years ago) (Machette, 1985).

A late Pleistocene age for loess in the Dolores area is indicated by a radiocarbon age of $15,970 \pm 155 \mathrm{yr}$ B.P. (SI-6137) (19,116 157 cal yr, Fairbanks and others, 2005), obtained from a vertebra of a semi-articulated musk ox (Symbos cavifrons) skeleton recovered from loess overlying a terrace along the Dolores River. The terrace, now under McPhee Reservoir, was about $10 \mathrm{mi}(16 \mathrm{~km})$ downstream from Dolores, Colorado (Clay and others, 1984; McDonald and others, 1987) and contained two loess units. The skeleton was preserved in the $\mathrm{Ck}$ horizon of the upper loess, and the radiocarbon age was interpreted as indicating that the last major period of loess deposition occurred no earlier than about $19,000 \mathrm{cal} \mathrm{yr}$, and probably began at about that time (Clay and others, 1984; McDonald and others, 1987; Price and others, 1988).

Holocene ages are indicated for loess deposits in the Hatch Point-Canyon Rims area of Utah. Here, loess deposits, are about $6 \mathrm{ft}(2 \mathrm{~m})$ thick and contain two units (Goldstein and others, 2010). On the basis of soil development, optically stimulated luminescence (OSL) ages, and one radiocarbon age, the lower unit was deposited between about 10,500 and $7,500 \mathrm{yr}$ B.P. and the upper unit was deposited between about 6,000 and $<1,400$ yr B.P. (Goldstein and others, 2010). Based on radiocarbon ages of carbon in soil carbonate and organic carbon concentrated from the loess at the "new garbage pit," loess 1 and 2 were thought to be deposited in two stages, one more than 4,000 radiocarbon years ago and the other more than 3,000 radiocarbon years ago, respectively (Arrhenius and Bonatti, 1965).

Deposition of loess is an ongoing process in the Four Corners area. Dust storms are common in this area during the spring and larger events leave a noticeable film of sticky, reddish silt (G. San Miguel, National Park Service, written commun., 2011). In the Canyonlands National Park area of Utah, ongoing eolian-silt additions to soils on upland sandstone surfaces have been demonstrated using mineralogical, magnetic, and geochemical data (Reynolds and others, 2001). Hence, the evidence suggests loess deposits in the southwest may have been deposited by different eolian events that span a wide range of ages.

\section{Colluvium Derived from the Menefee Formation}

\section{Introduction}

Colluvium, for the purposes of this map, is any loose, heterogeneous, and incoherent mass of soil material or rock fragments that were transported and deposited by gravity by 
slow mass-movement processes, chiefly creep. Because the Menefee Formation weathers so rapidly, there are few areas in the park, except for road cuts and landslide scars, where one can actually see this formation. This loose, weathered material derived from the Menefee Formation then creeps downslope to form a thick colluvial cover, which for the purpose of this report is mapped as a separate unit (Qcmf). These deposits comprise about $18.6 \mathrm{mi}^{2}\left(48 \mathrm{~km}^{2}\right)$, or about 18.5 percent of the map area. On slopes within the park this unit consists mainly of poorly stratified, poorly sorted, matrix- to clast-supported, cobbly boulder gravel. The unit also contains gray (10YR 6/1), clayey silt and pale-brown (10YR 6/3) fine sandy silt and pods of black (10YR 2/1) weathered coal and scattered white (10YR 8/2), angular sandstone pebbles, cobbles, and boulders. This colluvial cover is prone to failure on steep slopes and forms many of the landslides shown on the accompanying map. This unit also probably contains older landslide deposits that were not recognized in the field or on the aerial photographs because they do not have a well-defined morphology; hence, the number of landslides depicted on the map probably represent a minimum value.

\section{Location in the Map Area}

In the narrow valleys in the western map area the colluvium commonly mantles steep, now vegetated, slopes that extend from the base of the Cliff House Sandstone down to the valley axis virtually filling these valleys with colluvium. In the wider valleys in the eastern map area the colluvium mantles steep slopes that extend downward to the broad valley bottom. In the lower part of Morefield and Prater Canyons (fig. 1), the unit includes earthflow-like features that emanate from the Menefee Formation and consist of clast-supported lobes 6$10 \mathrm{ft}(2-3 \mathrm{~m})$ high. The lobes extend from the valley walls to near the valley axis. Movement here may have occurred on bentonite layers within the Menefee Formation.

\section{Geologic Mapping}

A variety of methods were used to map the surficial deposits and bedrock units in Mesa Verde National Park including: (1) compilation from existing geologic maps (Wanek, 1954, 1959; Haynes and others, 1972; Colton and others, 1975; Condon, 1991; and Griffitts, 1999); (2) stereoscopic analysis of 1:12,000-scale color National Park Service aerial photographs taken in 2004, and 1:40,000-scale black and white aerial photographs of the National Aerial Photography Program taken in 1999 (http://eros.usgs.gov/\#/Find_Data/ Products_and_Data_Available/Aerial_Products), and (3) fieldwork from 2006 to 2011. Where units were exposed and could be examined, detailed information was noted such as: geomorphic form, stratigraphic relationship, thickness, percentage of clasts, lithology of clasts, size range of clasts, degree of clast roundness (Powers, 1953), estimation of sand, silt, clay fraction of the matrix, matrix color, degree of sorting, type of bedding (if any), and vegetation cover. Data from these accessible areas were then extrapolated to the less accessible areas. In addition, samples were collected for grain-size analyses to better characterize specific units, and at several localities samples were also collected for radiocarbon and ${ }^{40} \mathrm{Ar} /{ }^{39} \mathrm{Ar}$ dating. Map unit boundaries were plotted on a digital orthophoto base with the use of a photogrammetric stereo plotting instrument (Kern PG-2). Metric units are now used exclusively in the following explanations and unit descriptions; conversions to English equivalents are given in the Conversion Factors at the front of this report. 


\section{Description Of Map Units}

\section{Surficial Deposits}

Surficial deposits in Mesa Verde National Park consist of artificial fill, alluvial, colluvial, landslide, and eolian deposits. Deposits shown on this map are generally greater than $1 \mathrm{~m}$ thick; thinner, discontinuous deposits are not shown and are incorporated with the underlying map unit. Residual material on bedrock and some artificial fills are not mapped. Many of the contacts between surficial map units are approximate because the contacts are commonly poorly exposed or gradational. For instance, the contacts between colluvial deposits derived primarily from the Menefee Formation (Qcmf) and adjacent landslides (primarily Qtr) within many of the canyons of the park are characteristically poorly exposed.

Previous geologic maps of Mesa Verde National Park (Griffitts, 1999) or the park and surrounding area (Wanek, 1954 and 1959; Haynes and others, 1972; Condon, 1991) show the Menefee Formation occupying large areas of the park. The trouble with this depiction is that there are very few areas in the park where one can actually see this formation because it is usually overlain by a thick colluvial cover prone to landsliding. The emphasis of this map is placed on the unconsolidated surficial deposits. Hence, in many areas the thick overlying colluvial cover (unit Qcmf) is shown on the map instead of the underlying Menefee Formation as shown on previous maps.

Divisions of Quaternary time that are given in the descriptions of the surficial deposits and shown in the front of the report and on the map sheet are modified from Bowen and Gibbard (2007) and U.S. Geological Survey (2010). They are: Holocene, 0 11,700 yr ago; late Pleistocene, 11,700-130,000 yr ago; middle Pleistocene, 130,000-780,000 yr ago; and early Pleistocene $780,000-2,588,000$ yr ago.

Age assignments for surficial deposits are based chiefly on stratigraphic relations, degree of erosional modification of original-surface morphology, degree of soil development, and radiometric ages.

Grain-size terminology for the surficial deposits is based on both visual estimates in the field and laboratory analyses. Grain-size analysis was carried out on more than 50 samples that included loess, alluvial, and colluvial units. Terminology follows the modified Wentworth grade scale (American Geological Institute, 1982). In descriptions of surficial deposits, the term "clast" refers to particles greater than $2 \mathrm{~mm}$ in diameter, whereas the term "matrix" refers to particles less than $2 \mathrm{~mm}$ in size.

Dry matrix colors of the surficial deposits were determined by comparison with a Munsell Soil Color Chart (Munsell Color, 1973). The colors of the surficial deposits reflect those of the sediments and (or) bedrock from which they are derived.

\section{Artificial-fill Deposits}

af

Artificial fill deposits (latest Holocene) —Compacted and uncompacted material composed mostly of varying amounts of silt, sand, and rock fragments derived from nearby bedrock or surficial deposits. Unit includes large fills beneath sections of the park entrance road consisting predominantly of locally derived pale-olive (5Y 6/3) silty sand containing scattered pebble- and cobble-size angular clasts derived from the Point Lookout Sandstone (Kpl). Unit also includes small stock pond dams in the northeastern map area that consist of pale-olive (5Y 6/3) sandy silt, silt, clayey silt, and silty clay derived from the nearby alluvial and colluvial deposits (Qac) in this area, that were in turn derived from the Mancos Shale (Km). Flat-topped mounds resulting from the infilling of two small reservoirs built by the Ancestral Puebloans in Morefield and Prater Canyons near the southern boundary of the park (Wright, 2006) are also included in this unit. These mounds, both about 60 to $70 \mathrm{~m}$ in diameter and 4.5 to $6 \mathrm{~m}$ high, consist of water-laid sands, silts, and clays (Wright, 2006). Thickness ranges from about $1 \mathrm{~m}$ to more than $10 \mathrm{~m}$

Hazard: poorly compacted fills may be subject to settlement when loaded.

\section{Alluvial Deposits}

Qa
Alluvium deposited by small ephemeral streams (Holocene and late Pleistocene) - Alluvium underlying ephemeral stream channels, low terraces, and flat valley floors in the lower reaches of Long, Navajo, and Soda Canyons. In Navajo Canyon and at one location in Soda Canyon, unit was deposited just upstream from landslide dams. Unit consists predominantly of brown (10YR 5/3) to yellowish-brown (10YR 5/4), massive to distinctly stratified, silty fine sand and fine sand. Locally contains minor amounts of dark yellowish-brown (10YR 4/4), silty clay beds. A charcoal fragment, about $330 \mathrm{~cm}$ below the surface in an exposure of silty clay in Navajo Canyon, yielded a radiocarbon age of 2,235 \pm 30 yr B.P. (WW-6350) $(2,257 \pm 59$ cal yr, Fairbanks and others, 2005). The exposure is just upstream from the large landslide that dammed the canyon and is visible from the Navajo Canyon View Point (figs. 1 and 4). The radiocarbon age: (1) provides a minimum age (probably a very minimum age) for the landslide, and (2) indicates a sedimentation rate of about $150 \mathrm{~cm} /$ $1,000 \mathrm{yr}$ behind the landslide dam. Estimated maximum thickness $20 \mathrm{~m}$

Hazard: low-lying areas of unit adjacent to stream channel may be subject to periodic flooding. 
Qam

Residual gravel (middle Pleistocene to Pliocene?) - Area of residual gravels, originally deposited by an ancestral Mancos River before the present valley system was developed (Atwood, 1911). Unit consists of scattered rounded and subrounded pebbles and cobbles and a few small boulders on a bedrock surface of Cliff House Sandstone (Kch). Gravels consist mainly of resistant lithologies, predominantly fine- and coarse-grained quartzite, with a few basalts and intermediate volcanics from the La Plata Mountains to the northeast. Unit is located on the high northern ends of Big Mesa and Whites Mesa (fig. 1) in the southeastern part of Mesa Verde National Park about 425 to $520 \mathrm{~m}$ above the Mancos River. In the park this unit is present only as areas of scattered clasts; south of the park, in the Ute Mountain Indian Reservation, near the southern end of Chapin Mesa these gravels range in thickness from 3 to $6 \mathrm{~m}$ (Pantea, 1996). A similar deposit near the town of Palisade, Colorado, about $210 \mathrm{~km}$ to the north was estimated to be about $3.8 \mathrm{~m} . \mathrm{y}$. based on the average rate of down cutting of the nearby Colorado River (Carrara, 2000).

Resource: quartzite clasts in this unit may have been used as a resource by the Ancestral Puebloans for axe heads, knives, and blades.

\section{Alluvial and Colluvial Deposits}

Alluvial and colluvial deposits, undivided (Holocene and late Pleistocene) — Predominately a mix of alluvium and colluvium, including sheetwash and debris-flow deposits. In the canyons in the eastern park area unit Qac consists mainly of fine-grained alluvium in narrow, incised ephemeral-stream channels and colluvium that extends from the base of adjacent slopes to the margins of the stream channel. Alluvium consists primarily of brown (10YR 4/3), grayish-brown (10YR 5/2), and yellowish-brown (10YR 5/4), massive to stratified, silt, silty fine sand and sand. In places contains angular to subrounded pebbles and cobbles of sandstone in beds and lenses $5-25 \mathrm{~cm}$ thick. Also, in some places contains beds of laminated silty fine sand and clayey silt $5-10 \mathrm{~cm}$ thick and thin buried soils (humic horizons). Colluvium consists predominantly of brown (10YR $4 / 3$ ), massive, silty fine sand with scattered subangular to subrounded sandstone pebbles and cobbles. Estimated maximum thickness $25 \mathrm{~m}$.

Resource: soils developed in this unit in the lower portions of both Morefield and Prater Canyons were used by the Ancestral Puebloans for farming as evidenced by the remains of two small reservoirs (Wright, 2006) and archeological sites in both of these canyons.

Hazard: low-lying areas of unit adjacent to stream channel may be subject to stream flooding and debris flows.

In parts of the northern map area unit Qac underlies large areas of low relief that are dissected in places by deep gullies. Here the unit consists of interbedded pale brown (10YR 6/2), silty fine sand layers and pebble gravel beds 5-25 cm thick. Gravel consists of mostly imbricated chips of Mancos Shale $(\mathrm{Km})$ and sparse sandstone pebbles from the Point Lookout Sandstone (Kpl). Also contains grayish-brown (10YR 5/2), massive to stratified, silty clay containing scattered pebbles derived from the Mancos Shale. Clayey alluvium is soft, sticky, and plastic where moist; tough, hard, and blocky where dry. Thickness $2-5 \mathrm{~m}$.

In parts of the eastern map area along the Mancos River unit Qac underlies areas of low relief that are dissected in places by deep gullies. Here, this unit also includes flash-flood and debris-flow deposits 1$2 \mathrm{~m}$ thick, consisting of light-brownish-gray (10YR 6/2), weakly stratified, silty fine sand containing scattered subangular to subrounded sandstone pebbles and cobbles. Also contains clast-supported gravel, about $1 \mathrm{~m}$ thick, consisting of subangular to subrounded sandstone pebbles, cobbles, and boulders. The largest boulders are about $1 \mathrm{~m}^{3}$. Matrix consists of yellowish-brown (10YR 5/4) medium sand. At a site in the southeastern park area the unit consists of $1 \mathrm{~m}$ of pebble gravel overlying $50 \mathrm{~cm}$ of poorly sorted, angular to 
subangular pebbly cobble gravel. Gravel consists primarily of sandstone clasts derived from the Point Lookout Sandstone (Kpl). Thickness 2-5 m.

Ages: radiocarbon ages were obtained from exposures in alluvium in this unit in Whites and Morefield Canyons near the southern park boundary. In Whites Canyon, a radiocarbon age of $350 \pm 30 \mathrm{yr}$ B.P. (WW-6348) (411 \pm 58 cal yr, Fairbanks and others, 2005) was obtained from a charcoal fragment collected at a depth of $120 \mathrm{~cm}$ in massive silty sand. In Morefield Canyon a radiocarbon age of $415 \pm 30 \mathrm{yr}$ B.P. (WW6349) (488 $28 \mathrm{cal}$ yr, Fairbanks and others, 2005) was obtained from a charcoal fragment at a depth of $130 \mathrm{~cm}$ in a sequence of sandy silts and silts. These radiocarbon ages indicate that the upper part of the alluvium in these canyons was deposited during the last several hundred years. Hence, the subsequent incision of these fills which resulted in the exposures from which the charcoal was collected occurred no more than several hundred years ago, and may have been in part aggravated by cattle grazing in these canyons prior to the establishment of the park in 1906 (Thompson, 2007, p. 8). An additional radiocarbon age of 8,315 $\pm 51 \mathrm{yr} \mathrm{B.P.}$ (WW-6818) (9,334 \pm 82 cal yr, Fairbanks and others, 2005) was obtained from a charcoal fragment collected at a depth of about $5 \mathrm{~m}$ in an exposure of light-yellowish-brown (10YR 6/4) massive, silty fine sandy alluvium near the head of Prater Canyon.

Hazard: in both the northern and eastern map areas, unit Qac is subject to piping (erosion by percolating water resulting in the formation of tunnels or pipes through which fine-grained material is removed) and gullying. Gullies within unit are subject to flash floods and debris flows. In these areas, unit may contain swelling clays. In addition, unimproved roads in these areas become sticky and very slippery when wet, and at times are virtually impassable.

Fan deposits (Holocene and late Pleistocene) - Fan-shaped deposits at the mouths of gullies and small tributaries in Morefield and Prater Canyons. Unit was deposited mainly by ephemeral stream flow, flash floods, and debris flows. Consists of dark-grayish-brown (10YR 4/2), brown (10YR 4/3, 5/3), and yellowish-brown (10YR 5/4), poorly stratified, unsorted, silty fine sand, sand, and pebbly sand. Clasts consist of subangular to subrounded sandstone pebbles derived from the Point Lookout Sandstone (Kpl). Unit locally includes colluvial deposits and sheetwash alluvium. Thickness $3-15 \mathrm{~m}$

Hazard: unit is subject to flooding or debris flows.

\section{Colluvial Deposits}

Qcmf Colluvial deposits derived from the Menefee Formation (Holocene and late Pleistocene)—On slopes underlain by the Menefee Formation (Kmf), this unit consists of mainly matrix- to clast-supported, cobbly boulder gravel deposited by mass-wasting processes, chiefly creep. Includes gray (10YR 6/1), clayey silt and pale-brown (10YR 6/3) fine sandy silt, containing pods of black (10YR 2/1) weathered coal, yellowishbrown (10YR 5/4), silty fine sand containing scattered white (10YR 8/2), angular to subangular sandstone pebbles, cobbles, and boulders derived from sandstone beds within the Menefee Formation and the overlying Cliff House Sandstone (Kch). Unit contains many boulders $>1 \mathrm{~m}^{3}$ in volume. In the narrow valleys in the western map area, the colluvium commonly mantles steep, vegetated, slopes that extend from the base of the overlying Cliff House Sandstone down to the valley axis, virtually filling these valleys with colluvium. In the eastern part of the map area, in the lower part of Morefield and Prater Canyons, unit includes earthflow-like features emanating from the Menefee Formation that consist of clast-supported lobes 2-3 $\mathrm{m}$ high extending from the valley walls to near the valley axis. Clasts consist of angular to subrounded pebble, cobble, and boulder-sized sandstone clasts in a matrix of yellowish-brown (10YR 5/4), silty sand. Movement may have occurred on bentonite layers within the Menefee Formation. Exposed thickness about 5 m; estimated maximum thickness $20 \mathrm{~m}$

Hazard: unit includes undifferentiated rockfall, debris-flow, and landslide deposits too small to show at map scale. Unit also probably contains older landslide deposits that were not recognized in the field or on the aerial photographs because they do not have a well-defined morphology. Hence, unit is subject to a wide range of geologic hazards.

Colluvial deposits derived from the Mancos Shale (Holocene and late Pleistocene)-Mapped at the base of slopes at the heads of Morefield and Prater Canyons. Consists of mainly poorly exposed light-brownish-gray (10YR 6/2), massive, sandy silt, silt and clayey silt containing scattered subangular sandstone pebbles and cobbles derived from the overlying Point Lookout Sandstone (Kpl). Estimated thickness 3-10 m

Hazard: unit may have moderate to high swelling potential due to presence of expansive clays and may also contains sulfate minerals that are corrosive to conventional concrete and metal pipes. 


\section{Landslide Deposits}

Rockfall deposit (late Holocene) - Areas of large, scattered subangular sandstone boulders deposited by rockfall. Mapped at several localities in the park: in Morefield and Prater Canyons south of the entrance road about 0.5 and $1.2 \mathrm{~km}$ respectively, and along the western side of Wetherill Mesa. In Morefield Canyon the deposit consists of about 100 boulders, derived from the Point Lookout Sandstone (Kpl) off the eastern side of the valley. The boulders are scattered over a distance of $250 \mathrm{~m}$ along the valley floor. Here the boulders are commonly more than $1 \mathrm{~m}^{3}$ and the largest boulder is approximately $100 \mathrm{~m}^{3}$. Some of the boulders have a lichen cover; others have little or no lichens, suggesting multiple rockfall events. In Prater Canyon the deposit consists of about 25 boulders, derived from the Point Lookout Sandstone, scattered over a distance of $50 \mathrm{~m}$ in the middle of the valley floor such that it is not clear what side of the valley they originated from. Here, many of the boulders are less than $1 \mathrm{~m}^{3}$ and the largest boulder is less than $10 \mathrm{~m}^{3}$. The two small deposits along the western side of Wetherill Mesa are derived from the Cliff House Sandstone (Kch).

Hazard: although rockfall deposits are mapped at only several locations where they are large enough to show at the map scale, rockfalls are common in Mesa Verde National Park. Many of the slopes beneath the Cliff House (Kch) and Point Lookout (Kpl) Sandstone cliffs are susceptible to rockfalls. For instance, the large landslide (Qtr) that can be viewed from the Navajo Canyon View Point contains many rockfall boulders derived from the Cliff House Sandstone on its surface (fig. 4). In February 2012, a large slab of rock came off the cliff of the Point Lookout Sandstone about $5 \mathrm{~km}$ from the park's entrance where the road traverses a steep slope along the eastern side of Point Lookout. As the slab fell it broke apart into large boulders one of which landed on the road (estimated at 18 metric tons) and another larger boulder (estimated at 218 metric tons) came to rest about 25 meters above the road and presented a further hazard to the road and traffic. Both boulders were subsequently blasted and removed (data accessed March 26, 2012 at http://www.nps.gov/meve/ parknews/12_06_rocking_meve.htm).

Debris-flow deposits (late Holocene) - Unit deposited by debris flows originating primarily from the Menefee Formation (Kmf) along the parks northern escarpment. Mapped unit consists of head scarp and lobate toe. Consists of poorly sorted and unstratified clast-supported pebble-cobble gravel with some boulders in a brown and pale-brown (10YR 5/3 and 6/3) silty sand matrix. Clasts are mainly angular and subangular sandstone. Largest clasts are about $1 \mathrm{~m}^{3}$. Also consists of light-brown (7.5YR 6/4) silty sand and sand, 1-2 m thick, containing scattered angular and subangular sandstone cobbles and boulders. Recent debris flows are indicated by scarring of the vegetation. Estimated thickness as much as $10 \mathrm{~m}$

Hazard: areas within unit may be subject to flash floods or debris flows.

Earthflow deposit (Holocene) - Unit deposited by earthflow originating within the Menefee Formation (Kmf). Unit consists of matrix to clast supported, unsorted, yellowish-brown (10YR 5/4), silty fine sand that contains subangular to subrounded sandstone clasts. Mapped at one location in the park; approximately $1 \mathrm{~km}$ southeast of Park Point, where it descends a steep slope and forms a lobate toe at head of School Section Canyon (fig. 1). Estimated thickness about $10 \mathrm{~m}$

Hazard: unit is probably stable unless its vegetation cover is removed or its toe is excavated.

Translational and rotational landslide deposits (Holocene and late Pleistocene) - Unit consists of heterogeneous mixture of unconsolidated surficial material and rock fragments in a wide range of sizes deposited primarily by translational and rotational types of movement (Varnes, 1978). The size and lithology of the clasts and grain-size of the matrix depend on the various bedrock and surficial units involved in the landslide. Unit mapped primarily in the canyons of the park and along the entrance road on the eastern side of Point Lookout, and is derived mainly from the Menefee Formation (Kmf) and Mancos Shale $(\mathrm{Km})$. In some instances a landslide deposit originating from a valley wall abuts a landslide deposit originating from the opposite valley wall, such as near the head of Morefield Canyon. Here, a landslide from the western valley wall abuts a larger landslide that originated from the eastern valley wall. In these instances a contact is shown between the two landslides to indicate they are indeed separate landslide deposits. Unit may locally include small alluvial and talus deposits too small to show at the map scale.

Landslide deposits derived from the Menefee Formation consist of unsorted, unstratified, pale-yellow (5Y 7/4), light-yellowish-brown (2.5Y 6/4), and dark-grayish-brown (10YR 4/2) silty sand and sandy silt. These deposits commonly contain angular and subangular sandstone clasts derived from within the Menefee Formation or the overlying Cliff House Sandstone (Kch). The Menefee Formation forms many large translational and rotational landslides within the canyons of the park. An excellent example of one of these 
large landslides can be observed from Navajo Canyon View Point (fig. 4). Here, the landslide forced the ephemeral-stream channel to the eastern side of the canyon that temporarily dammed the canyon and formed a flat-valley floor underlain by alluvium $(\mathrm{Qa})$ upvalley from the landslide.

Landslide deposits derived from the Mancos Shale are unstratified, pale-brown (10YR 6/3) sandy silt, silt, clayey silt, and silty clay. Along the entrance road, on the eastern side of Point Lookout (fig. 1), failure was found to be translational because it occurred on a slip plane separating weathered Mancos Shale from underlying unweathered Mancos Shale (Plazak, 1989). These deposits commonly contain about 5-10 percent angular to subangular sandstone cobbles and boulders derived from the overlying Point Lookout Sandstone (Kpl). An excellent example of a large landslide in the Mancos Shale is found at the head of Morefield Canyon. This area is below the stratigraphic boundary of the Mancos Shale and the overlying Point Lookout Sandstone, yet on a drive along the roads in this area one notices many large blocks of Point Lookout Sandstone and a hummocky topography typical of a landslide area. Here, many boulders are more than $1 \mathrm{~m}^{3}$. In the roadcut at Nusbaum Gap (fig. 1), the pass on the entrance road between Mancos and Morefield Canyons, one can see an exposure showing intact Mancos Shale on the east, the slip surface of the large landslide, and the rubble of the large landslide in Morefield Canyon on the west. Based on the aerial extent and topographic relief between the landslide head and toe, some of the larger landslides in the park may exceed $30 \mathrm{~m}$ in thickness

Hazard: as previously mentioned many of the landslides depicted on this map are probably stable because they date to the Pleistocene and hence may have formed under a different climatic regime. However, the recognition of these landslides is important because natural and human-induced factors can alter stability. Reduction of lateral support by erosion, excavations, or roadcuts, removal of vegetation by fire or development, or an increase in pore pressure by heavy rains, may result in a reduction of shear strength and the reactivation of landslides or parts of landslides. Some landslides in the park indicate that landsliding is still an ongoing process. As previously mentioned, the only entrance road into the park traverses a steep slope of Mancos Shale along the eastern side of Point Lookout. Plazak (1989) documented a history of landslides along this section of road that he compiled from many different sources. One of the more notable landslide events Plazak (1989) was able to document occurred during the spring of 1979 when a series of landslide movements along the east side of Point Lookout closed the entrance road for more than a month (Plazak, 1989; Smith, 2002).

Rock-rubble deposits (Holocene and Pleistocene) —Deposited by rock topples, rockfall, rock avalanches, and debris flows below the northern and eastern escarpments of the park. Consists mainly of clast-supported, unsorted, unstratified to poorly stratified, pebbly, cobble-boulder gravel. Clasts consist of angular to subangular sandstone pebbles, cobbles, and boulders derived from the Point Lookout Sandstone (Kpl). Boulders commonly $>1 \mathrm{~m}^{3}$; one boulder capping a small hill west of the park's entrance station was estimated to be about $75 \mathrm{~m}^{3}$ in volume. Matrix consists of pale-brown (10YR 6/3), yellowish-brown (10YR 5/6), or paleyellow $(2.5 \mathrm{Y} 7 / 4)$ silty sand to sand. Unit underlies steep slopes along the northern and eastern escarpments and also caps isolated hills and ridges beyond the base of the escarpments. These hills and ridges stand above the general terrain because the sandstone rubble, acting as a protective cap, shields the underlying Mancos Shale $(\mathrm{Km})$ from erosion. As previously mentioned, a deposit on a hill near the entrance station to Mesa Verde National Park demonstrates an ancient age for some of the rock-rubble deposits shown on the map. The hill, at an elevation of 2,252 m, is approximately $91 \mathrm{~m}$ above the surrounding terrain and is capped by about $9 \mathrm{~m}$ of Point Lookout Sandstone rubble. The rubble consists of sand to boulders as large as $3 \mathrm{~m}$ in intermediate diameter and was emplaced by a large rockfall, rock avalanche, or debris flow originating from the Point Lookout Sandstone. That this hill is now $91 \mathrm{~m}$ above the surrounding terrain of Mancos Shale and the nearest outcrop of Point Lookout Sandstone is at Point Lookout, about $2.4 \mathrm{~km}$ to the south, suggests that an extended period of erosion, possibly on the order of several hundreds of thousands of years, has occurred since the deposition of this deposit. Thickness commonly 5 to as much as $30 \mathrm{~m}$

Hazard: areas around unit may be prone to rockfall or dislodged large sandstone boulders.

\section{Eolian Deposits}

Loess (Holocene to middle Pleistocene) - Poorly exposed predominantly reddish-brown (5YR 4/4 and 5/3) to yellowish-red (5YR 5/6), massive, fine sandy silt and silt deposited by wind probably from the desert to the southwest. In the Mesa Verde National Park area, unit rests unconformably on the bedrock surface of the Cliff House Sandstone (Kch) and forms a thick, continuous blanket on many of the mesa surfaces. Areas of loess shown on this map were taken from Ramsey (2003) with slight modification and correspond to 
his Morefield loam units. Size analyses of 19 samples indicate the loess commonly consists of 30 percent fine sand, 50 percent silt, and 20 percent clay. Arrhenius and Bonatti (1965) found that the loess consists predominantly of subrounded, goethite-stained quartz with lesser amounts of plagioclase and chlorite, and with amphibole and opaque minerals as accessories. Maximum thickness estimated to be $3-5 \mathrm{~m}$

Resource: the loess was a resource for the Ancestral Puebloans who farmed the soil that developed in the thick loess deposits, which because of its particle size distribution has good moisture retention properties (Price and others, 1988). This loess cover and the seasonal rains associated with the "Arizona monsoon" allowed these people to grow their crops, primarily corn, beans, and squash on the broad mesa tops. In addition, the loess was used as a mortar in the cliff dwellings.

Hazard: susceptible to soil erosion after fires and (or) removal of vegetation.

\section{Bedrock Units}

Minette dike (Oligocene) - A potassic (K) mica lamprophyre, greenish-gray to black in color, characterized by an aphanitic groundmass of sanidine, diopside, phlogopite, and apatite, and phenocrysts of diopside, and phlogopite, and less commonly olivine (Semken, 2003). Phenocrysts are commonly $1 \mathrm{~mm}$ to $1 \mathrm{~cm}$ in maximum dimension and comprise less than 10 percent to more than 50 percent of the rock (D.A. Gonzales, Fort Lewis College, written commun., 2011). At several locations in the area, minette dikes and diatremes contain calcite and fluorite breccias that appear to have formed from magmatic volatiles (Gonzales and others, 2010). Minettes are enriched in potassium $\left(\mathrm{K}_{2} \mathrm{O}\right.$ approximately 6 percent by weight) and magnesium, and depleted in aluminum (Semken, 2003). Wave-length dispersive XRF on a sample from the minette dike in Navajo Canyon yielded the following results: $\mathrm{SiO}_{2} 59.0$ percent; $\mathrm{Al}_{2} \mathrm{O}_{3} 11.32$ percent; $\mathrm{FeTO}_{3} 5.23$ percent; $\mathrm{MgO}$ 7.06 percent; $\mathrm{CaO} 6.91$ percent; $\mathrm{Na}_{2} \mathrm{O} 1.74$ percent; $\mathrm{K}_{2} \mathrm{O} 6.90$ percent; $\mathrm{TiO}_{2} 1.07$ percent; $\mathrm{P}_{2} \mathrm{O}_{5} 0.68$ percent; and $\mathrm{MnO} 0.07$ percent (T.L. Hannah, U.S. Geological Survey, written commun., 2006). Minettes form from a potassic lamprophyre melt; such melts originate at the crust-mantle boundary (Gerhardt and others, 2006). Occurs as discontinuous dikes, trending northeast, at several localities in Mesa Verde National Park and as dikes and diatremes in nearby areas (Wanek, 1959; Condon, 1991). Where exposed, minette commonly weathers to a yellowish-brown friable rock that disintegrates into angular to subangular, coarse sand-sized fragments, due primarily to the high concentrations of mica.

Dikes are well exposed in the soft Menefee Formation and Mancos Shale, and form gullies where they have intruded into the more resistant Cliff House and Point Lookout Sandstones. Along the eastern side of Navajo Canyon a minette dike, trending approximately $\mathrm{N} 20^{\circ} \mathrm{E}$ is dark gray, near vertical, about 3-5 $\mathrm{m}$ wide, and rises about 10-15 $\mathrm{m}$ above the surrounding Menefee Formation (Kmf). This dike extends to the southwest and a small outcrop occurs on the west side of Navajo Canyon protruding above a thick colluvium (Qcmf) cover. The dike can be traced farther to the southwest and forms a straight-line gully in the Cliff House Sandstone (Kch) as it crosses Long Mesa. A poorly exposed dike to the north, trending $\mathrm{N} 35^{\circ} \mathrm{E}$, underlies a gully, about 5-10 m deep, in the Cliff House Sandstone on both sides of Spruce Canyon. In Mancos Canyon a minette dike, that intrudes the Mancos Shale $(\mathrm{Km})$, can be traced intermittently for a distance of about $0.65 \mathrm{~km}$. At its northeastern end the dike is about $2 \mathrm{~m}$ wide, commonly less than $1 \mathrm{~m}$ above the surrounding ground surface, and trends $\mathrm{N} 38^{\circ} \mathrm{E}$. At its southwestern end the dike is about $75 \mathrm{~cm}$ thick, near vertical, and stands about 5-6 m above the adjacent Mancos Shale. Here, a 10-cm-thick bake zone of slate, derived from the Mancos Shale, surrounds the dike.

Age: An Oligocene age (33.9-23.03 Ma, U.S. Geological Survey, 2010) is indicated by two radiometric ages obtained from minette dikes in Mesa Verde National Park. $\mathrm{A}^{40} \mathrm{Ar} /{ }^{39} \mathrm{Ar}$ age of $25.65 \pm 0.08 \mathrm{Ma}$ was obtained on biotite from a sample of the minette dike exposed in Navajo Canyon and is interpreted as the intrusion age of the dike (Peters, 2011a). An additional ${ }^{40} \mathrm{Ar} /{ }^{39} \mathrm{Ar}$ age of $24.97 \pm 0.12 \mathrm{Ma}$ was obtained on phlogopite from a sample of the minette dike exposed in Mancos Canyon and was again interpreted as the intrusion age of this dike (Peters, 2011b).

Resource: the Ancestral Puebloans used minette for several purposes. Because minette is friable and crumbles into sand-sized particles when it weathers, it was sometimes used as a temper in the pottery of the Ancestral Puebloans (Gerhardt and others, 2006; Arakawa and Gonzales, 2010). Aphanitic minette, a dark-colored, very fine-grained, hard, dense rock that is flakable, was used as a lithic resource (arrow heads, blades, scrapers) by the Ancestral Puebloans (Gerhardt and others, 2006). In Morefield Canyon the author noted a large piece of minette that had been used as a metate (a grinding stone). In addition, because the minette dikes weather to form deep gullies in the Cliff House Sandstone, these gullies were used as travel routes from the canyon bottoms to the mesa tops by the Ancestral Puebloans (Linda Martin, National Park Service, personal commun., Sept. 11, 2006). 
Mesaverde Group (Upper Cretaceous)-Name applied to sandstones and coal-bearing units of Late Cretaceous age over large areas of the Rocky Mountains and the Southwest (Wanek, 1959). In Mesa Verde National Park the group comprises, from youngest to oldest, the Cliff House Sandstone, Menefee Formation, and Point Lookout Sandstone

Kch Cliff House Sandstone-Predominantly sandstone and minor siltstone, deposited in a shallow, near-shore marine environment of an advancing sea (Griffitts, 1990). In the northern part of the park the Cliff House Sandstone consists of yellowish-gray to yellowish-brown, fine-grained sandstone beds, as much as $3 \mathrm{~m}$ thick, but mostly consists of thin beds of soft sandstones and yellowish-gray shale, which wedge out to the south (Wanek, 1959, p. 695; Griffitts, 1990, p. 18). Here the unit forms slopes underlain by a thin colluvial cover consisting of unsorted, poorly stratified, clast-supported, angular to subangular, sandstone blocky rubble in a yellowish-brown (10YR 5/4) sandy matrix. In the southern part of the park this unit consists of two massive, white, yellowish-orange, brownish-yellow, and pale-brown fine- to medium-grained, cross-bedded, cliffforming sandstones separated by a thin, softer sandy shale section (Griffitts, 1990, p. 20). Iron concretions are common in the Cliff House Sandstone in the southern park area and are usually about 1 to $5 \mathrm{~cm}$ in diameter. Chemical analysis of two concretions indicated they consisted of 64 and 86 percent $\mathrm{Fe}_{2} \mathrm{O}_{3}$ respectively (Debbie Waldon, SGS Lakefield Research Limited, written commun., 2008). At some locations in the park, such as along the trail to Spruce Tree House, near the park headquarters, the Cliff House Sandstone weathers into a polygonal pattern of grooves sometimes called "turtlebacks" (Griffitts, 1990, p. 20). In the park this unit underlies the broad mesa tops common in the southern portion of the park that can be readily viewed from the Far View Visitor Center. In the Mesa Verde National Park area, the Cliff House Sandstone intertongues at its base with the underlying Menefee Formation (Kmf) and the contact between the two units is usually placed directly above the uppermost coal bed (Griffitts, 1990, p. 54). In the northern part of the park the thickness of the Cliff House Sandstone was estimated to be about 20 m (Griffitts, 1990, p. 20), although some upper strata may have been removed by erosion. In the southern part of the park a maximum thickness of about $120 \mathrm{~m}$ is exposed in the Echo Cliff area (Wanek, 1959, p. 695).

Resources: upper massive sandstone unit forms the deep alcoves that were used by the Ancestral Puebloans as building sites for their cliff dwellings. In addition, blocks of the Cliff House Sandstone were used as building material by the Ancestral Puebloans for their dwellings and for metates to grind their corn. More recently, many of the buildings constructed by the National Park Service, such as those at the park headquarters and museum were also constructed of blocks quarried from the Cliff House Sandstone.

Hazards: rockfalls have occurred along the massive cliffs and in the alcoves (Anderson, 1963).

Kmf Menefee Formation-Poorly exposed gray to grayish-orange lenticular cross-bedded sandstone and gray to brownish-gray and black carbonaceous shale, coal beds, and bentonitic clay beds. This formation was deposited in a broad coastal plain environment (Condon, 1991) adjacent to the Late Cretaceous sea. Informally divided into upper coal-bearing member, middle barren member, and lower coal-bearing member (Hayes and Zapp, 1955). The upper coal-bearing member consists of carbonaceous shale and lenticular coal beds interbedded with sandstone and siltstone beds (Condon, 1991). The middle barren member consists of massive, lenticular, cliff-forming, cross-bedded, light gray, fine- to medium-grained sandstone interbedded with siltstone and silty shale (Wanek, 1959; Griffitts, 1990; Condon, 1991). Abundant ironstone concretions occur in the sandstone or in the intervening shale (Wanek, 1959; Griffitts, 1990). The lower coal-bearing member consists of a yellowish-gray siltstone, carbonaceous shale, and coal interbedded with minor amounts of very fine to fine-grained sandstone. Conformably overlies and intertongues at its base with the Point Lookout Sandstone (Kpl) (Wanek, 1959). In the park, the contact between the continental Menefee Formation and the underlying marine Point Lookout Sandstone is easily recognized. The lower layers of the Menefee are very dark brown or black soft shales with thin beds of shiny black coal, that weather to form a colluvial slope, whereas the top of the Point Lookout Sandstone consists of a massive, yellow, yellowish-gray, light-gray, pale-orange, and pale-brown, fine- to medium-grained, cliff-forming, cross-bedded sandstone. In the Mesa Verde area, the Menefee Formation is about 105-120 m thick, although it reaches a thickness of about $245 \mathrm{~m}$ at the Colorado-New Mexico boundary (Wanek, 1959, p. 688)

The Menefee Formation weathers rapidly and this loose weathered material then creeps downslope to form a thick colluvial mantle. Hence, except for road cuts and landslide scars, there are few good exposures of this formation in the park. On this map the majority of colluvium (Qcmf) mapped along the sides of canyons is derived from this formation. 
Resource: the Ancestral Puebloans used bentonitic clay layers within the Menefee for their pottery and farmed both the soils formed in this unit and colluvium derived from this unit in the broad Morefield and Prater Canyons in the eastern park area. Iron concretions from the Menefee Formation were used for hand axes and red ocher was obtained from the hematite in these concretions. Iron concretions and jet (carbonized wood) were also carved into decorative pendants, on display in the park's museum. Coal beds in the park are relatively thin, usually not more than $50 \mathrm{~cm}$ thick and mostly thinner, but outside the park they are considerably thicker and have been mined (Griffitts, 1990, p. 53). In the early 1900s coal was mined from the Menefee Formation south of the towns of Mancos (Collier, 1919), and Cortez (Wanek, 1959). The Ancestral Puebloans do not appear to have utilized the coal resources for cooking or heating (Linda Martin, National Park Service, personal commun., Sept. 11, 2006). The Menefee Formation is also a rich resource for terrestrial fossils (Griffitts, 1990).

Hazard: the Menefee Formation is prone to failure on steep slopes and forms many landslides within the canyons of the park. Much of the road between Montezuma Valley Overlook and the Park Point turnoff is in the Menefee Formation. Parts of this section of the road have had to be rerouted because where the road was in unstable soft woody shales and thin-bedded brittle coal layers it was difficult to maintain (Griffitts, 1990, p. 14-15). In addition, exposed coal seams can ignite in wildfires as occurred in Morefield Canyon in 2000. Because the smoldering coal posed a risk of future ignitions it was extinguished through excavation with heavy machinery in 2005 (G. San Miguel, National Park Service, written commun., 2005).

Point Lookout Sandstone-Predominantly sandstones and shales deposited as barrier beaches and near-shore sands in a shallow-water retreating sea (Griffitts, 1990). The upper part of the Point Lookout Sandstone consists of massive beds of yellow, yellowish-gray, light-gray, pale-orange, and pale-brown, fine- to medium-grained, cross-bedded sandstones and forms the light-colored cliffs capping the mesas along the north face of Mesa Verde seen from U.S. Route 160. Along the trail on the western side of Prater Ridge, a large flat surface of the upper part of the Point Lookout Sandstone has weathered into a polygonal pattern of grooves called "turtlebacks" by Griffitts, (1990, p. 20). This upper part also contains radioactive black sandstone deposits along the western and southwestern sides of Mesa Verde (Houston and Murphy, 1977). The lower part of the Point Lookout Sandstone consists of interbedded yellowish-gray and light-brown, finegrained, cross-bedded sandstone and olive-gray to gray sandy fossiliferous shale. Sandstone beds in lower part increase up section in thickness and abundance. Conformably overlies the Mancos Shale $(\mathrm{Km})$, with which the basal part also intertongues. On some steep slopes a thin colluvial cover may form consisting of unsorted, poorly stratified, clast-supported, angular to subangular, sandstone pebbles, cobbles, and boulders in a yellowish-brown (10YR 5/4), silty fine sand or sandy matrix. Many of the clasts have a thin coating of calcium carbonate. Along the northern escarpment sections of the upper part of the Point Lookout Sandstone measured by Wanek (1959) indicate a thickness of about $75 \mathrm{~m}$, whereas sections of the lower part range between 25 and $38 \mathrm{~m}$.

Resource: some of the small alcoves formed in the upper massive sandstones, were occupied by the Ancestral Puebloans (Griffitts, 1990, p. 53). In addition, this unit was sometimes used as metates to grind corn.

Hazard: because the Point Lookout Sandstone forms cliffs and steep slopes and is underlain by the easily weathered and eroded Mancos Shale, slopes beneath the Point Lookout Sandstone are prone to rockfall

Mancos Shale (Upper Cretaceous) - Mostly a thick sequence of gray to black fissile shale interbedded with thin beds, generally less than $25 \mathrm{~cm}$ thick, of tan siltstone, fine-grained sandstone and limestone deposited in a deep-water marine environment. Fossils found in this formation include oysters, clams, snails, shark teeth, and ammonites. Mancos Shale slopes beneath outcrops of the Point Lookout Sandstone (Kpl) may be covered with a thin mantle of sandstone boulders not shown on this map. Unit intertongues at top with lower part of the Point Lookout Sandstone. On this map the upper boundary of the Mancos Shale is placed at the base of the lowermost sandstone of the Point Lookout Sandstone. Conformably overlies Dakota Sandstone in nearby areas. Weathered Mancos Shale or colluvium derived from the Mancos Shale has a gray "popcorn" texture when dry. Near the park entrance, in the section below Point Lookout (fig. 1), Wanek (1959) measured about $610 \mathrm{~m}$ of Mancos Shale, but excluded the transitional zone with the overlying Point Lookout Sandstone. Leckie and others (1997) measured a total Mancos Shale thickness of about $685 \mathrm{~m}$ in this same area. 
Hazards: unit prone to landsliding and debris flows where exposed on steep slopes, such as along the northern and eastern escarpments of Mesa Verde National Park. Along these escarpments many of the slopes underlain by the Mancos Shale are steep and bare of vegetation, indicating high rates of erosion and ongoing mass wasting processes. Unit may have moderate to high swelling potential due to presence of expansive clays; contains sulfate minerals that are corrosive to conventional concrete and metal pipes. When wet, the surface of the Mancos Shale becomes sticky and very slippery, unimproved roads are virtually impassable when wet. 


\section{References Cited}

American Geological Institute, 1982, Grain-size scales used by American geologists, modified Wentworth scale, in Data sheets ( $2 \mathrm{~d}$ ed.): Falls Church, Va., American Geological Institute, sheet 17.1.

Anderson, L.D., 1963, Erosion versus man at Mesa Verde: Mines Magazine, v. 53, p. 11-13.

Arakawa, Fumiyasu, and Gonzales, D.A., 2010, A geoarchaeological investigation on the origin of sanidine-bearing volcanic temper in pottery sherds from the four corners area [abs.]: Geological Society of America Abstracts with Programs, v. 42, no. 5, p. 153.

Arrhenius, Gustaf, and Bonatti, Enrico, 1965, The Mesa Verde loess, in Osborne, D, ed., contributions of the Wetherill Mesa Archeological Project, Memoirs of the Society for American Archeology no. 18: Salt Lake City, Utah, University of Utah. p. 92-100.

Atwood, W.W., 1911, A geographic study of the Mesa Verde: Annals of the Association of American Geographers, v. 1, p. $95-100$.

Bettis III, E.A., Muhs, D.R., Roberts, H.M., Wintle, A.G., 2003, Last glacial loess in the conterminous USA: Quaternary Science Reviews, v. 22, p. 1907-1946.

Bohman, R.A., 1958, Tunnel construction in the Mancos Shale Formation on U.S. Bureau of Public Roads Project 1-F, Mesa Verde National Park, Colorado: Geological Society of America, Engineering Geology Case Histories no. 2, p. 67.

Bowen, D.Q., and Gibbard, P.L., 2007, The Quaternary is here to stay: Journal of Quaternary Science, v. 22, p. 3-8.

Carrara, P.E., 2000, Geologic map of the Palisade Quadrangle, Mesa County, Colorado: U.S. Geological Survey Miscellaneous Field Investigations, Map MF-2326, scale 1:24,000.

Clay, V.L., Neusius, S.W., and Canaday, T.W., 1984, Symbos sp. recovered from loess deposits in southwest Colorado [abs.]: Geological Society of America Abstracts with Programs, v. 16, no. 4, p. 218

Cobban, W.A., Walaszczyk, Ireneusz, Obradovich, J.O., and McKinney, K.C., 2006, A USGS zonal table for the Upper Cretaceous Middle Cenomanian-Maastrichtian of the western interior of the United States based on ammonites, inoceramids, and radiometric ages: U.S. Geological Survey Open-File Report 2006-1250, 50 p.

Collier, A.J., 1919, Coal south of Mancos, Montezuma County, Colorado: U.S. Geological Survey Bulletin 691-K, p. 293-310.
Colton, R.B., Anderson, L.W., Holligan, J.A., Patterson, P.E., and Shaver, K.C., 1975, Preliminary map of landslide deposits, Cortez $1^{\circ} \times 2^{\circ}$ quadrangle, Colorado and Utah: U.S. Geological Survey Miscellaneous Field Studies Map MF-699, scale 1:250,000.

Condon, S.M., 1991, Geologic and structure contour map of the Ute Mountain Ute Indian Reservation and adjacent areas, southwest Colorado and northwest New Mexico: U.S. Geological Survey Miscellaneous Investigations Series Map I-2083, scale 1:100,000.

Dobrovolny, Ernest, Lindvall, R.M., and Bohman, R.A., 1954, Engineering geology of the Knife Edge Highway relocation and tunnel site, Mesa Verde National Park, Colorado: Geological Society of America Bulletin, v. 65, p. 1374.

Fairbanks, R.G, Mortlock, R.A., Chiu, T.-C., Cao, L., Kaplan, A., Guilderson, T.P., Fairbank, T.W., Bloom, A.L., Grootes, P.M., and Nadeau, M.-J., 2005, Marine radiocarbon calibration curve spanning 0 to 50,000 years B.P., based on paired ${ }^{230} \mathrm{Th} /{ }^{234} \mathrm{U} /{ }^{238} \mathrm{U}$ and ${ }^{14} \mathrm{C}$ dates on pristine corals: Quaternary Science Reviews, v. 24, p. 1781-1796.

Floyd, M.L., Romme, W.H., and Hanna, D.D., 2000, Fire history and vegetation pattern in Mesa Verde National Park, Colorado: U.S.A. Ecological Applications, v. 10, p. 1666-1680.

Gerhardt, Kimberlee, Arakawa, Fumiyasu, and Gonzales, D.A., 2006. Raw lithic resources associated with minette dikes and diatremes in and around Mesa Verde National Park: Mesa Verde National Park Library, Report for Mesa Verde National Park scientific research study no. MEVE20049.

Goldstein, H.L., Reheis, M.C., Miller, M.E., Reynolds, R.L., Forman, S.L., Belnap, Jayne, and Yount, J.C., 2010, Physical characteristics and ages of loess deposits in the Hatch Point-Canyons Rims area, and correlation to aeolian and fluvial records in southwestern Utah [abs.]: Geological Society of America Abstracts with Programs, v. 42, no. 5, p. 312.

Gonzales, D.A., Turner, B.E., Burgess, R.T., Holnback, C.C., and Critchley, M.R., 2010, New insight into the timing and history of diatreme-dike complexes of the northeastern Navajo Volcanic Field, southwestern Colorado: New Mexico Geological Society Guidebook, 61st field conference, p. 163-172.

Griffitts, M.O., 1990, Guide to the geology of Mesa Verde National Park: Salt Lake City, Utah, Mesa Verde Museum Association, Inc. Lorraine Press, 88 p.

Griffitts, M.O., 1999, Mesa Verde National Park Geology: National Park Service, scale 1:24,000. 
Hayes, P.T., and Zapp, A.D., 1955, Geology and fuel resources of the Upper Cretaceous rocks of the Barker Dome-Fruitland area, San Juan County, New Mexico: U.S. Geological Survey Oil and Gas Investigations Map OM-144, scale 1:62,000.

Haynes, D.D., Vogel, J.D., and Wyant, D.G., 1972, Geology, structure, and uranium deposits of the Cortez quadrangle, Colorado and Utah: U.S. Geological Survey Miscellaneous Investigations Series Map I-629, scale 1:250,000.

Houston, R.S., and Murphy, J.F., 1977, Depositional environment of Upper Cretaceous black sandstones of the Western Interior: U.S. Geological Survey Professional Paper 994-A, $29 \mathrm{p}$.

Hunt, C.B., 1956, Cenozoic geology of the Colorado Plateau: U.S. Geological Survey Professional Paper 279, 99 p.

Leckie, R.M., Kirkland, J.I., and Elder, W.P., 1997, Stratigraphic framework and correlation of a principal reference section of the Mancos Shale (Upper Cretaceous), Mesa Verde, Colorado, in Mesozoic geology and paleontology of the Four Corners region: New Mexico Geological Society Guidebook, 48th Annual Field Conference, p. 163-216.

Machette, M.M., 1985, Calcic soils in the southwestern United States, in Weide, D.L., and Faber, M.L., eds., Soils and Quaternary geology of the southwestern United States: Geological Society of America Special Paper 203, p. 1-21.

Martin, Linda, 2005, Mesa Verde-The story behind the scenery: Wickenburg, Ariz., KC Publications, Inc., 48 p.

McDonald, J.N., Neusius, S.W., and Clay, V.L., 1987, An associated partial skeleton of Symbos cavifrons (Artiodactyla: Bovidae) from Montezuma County, Colorado: Journal of Paleontology, v. 61, no. 4, p. 831-843.

Munsell Color, 1973, Munsell soil color charts: Baltimore, Md., Kollmorgen Corp., Macbeth Division.

Pantea, M.P., 1996, Preliminary evaluation of potential construction-grade sand, gravel, and limestone deposits on the Ute Mountain Reservation, in Huffman, A.C., Jr., Lund, W.R., and Godwin, L.H., eds., Geology and Resources of the Paradox Basin, Utah Geological Association Guidebook 25 , p. $77-85$.

Peters, Lisa, 2011a, ${ }^{40} \mathrm{Ar} /{ }^{39} \mathrm{Ar}$ Geochronology results from a Navajo Canyon dike in Mesa Verde National Park: New Mexico Bureau of Geology and Mineral Resources Open File Report OF-AR-35, 7 p.

Peters, Lisa, 2011b, ${ }^{40} \mathrm{Ar} /{ }^{39} \mathrm{Ar}$ Geochronology results from a Mancos Canyon dike in Mesa Verde National Park: New Mexico Bureau of Geology and Mineral Resources Open File Report OF-AR-36, 7 p.
Plazak, D.J., 1989, Soil mechanics of the Point Lookout landslide, Montezuma County, Colorado: Golden, Colo., Colorado School of Mines, Master's thesis, 248 p.

Powers, M.C., 1953, A new roundness scale for sedimentary particles: Journal of Sedimentary Petrology, v. 23, p. 117-119.

Price, A.B., Nettleton, W.D., Bowman, G.A., and Clay, V.L., 1988, Selected properties, distribution, source, and age of eolian deposits and soils of southwest Colorado: Soil Science of America Journal, v. 52, p.450-455.

Ramsey, D.K., 2003, Soil survey of Cortez Area, Colorado, parts of Dolores and Montezuma Counties: U.S. Department of Agriculture, Natural Resources Conservation Service, U. S. Department of Agriculture, $632 \mathrm{p}$.

Reynolds, Richard, Belnap, Jayne, Reheis, Marith, Lamothe, Paul, and Luiszer, Fred, 2001, Aeolian dust in Colorado Plateau soils-Nutrient inputs and recent change in source: Proceedings of the National Academy of Sciences, v. 98, p. 7123-7127.

Semken, S.C., 2003, Black rocks protruding up —The Navajo Volcanic Field, in Lucas, S.G., Semken, S.C., Berglof, W.R., and Ulmer-Scholle, D., eds., Geology of the Zuni Plateau: New Mexico Geological Society, Fifty-fourth Annual Field Conference, September 24-27, 2003, p. 133-138

Smith, D.A., 2002, Mesa Verde National Park- Shadows of the centuries, rev. ed.: Boulder, Colo., University Press of Colorado, $275 \mathrm{p}$.

Thompson, Erika, 2007, Mesa Verde's hidden landscape; designing a National Park: Mesa Verde Museum Association, $161 \mathrm{p}$.

U.S. Geological Survey Geologic Names Committee, 2010, Divisions of geologic time-Major chronostratigraphic and geochronologic units: U.S. Geological Survey Fact Sheet 2010-3059, 2 p.

Varnes, D.J., 1978, Slope movement types and processes, in Schuster, R.L., and Krizek, R.J., eds., Landslides; analysis and control: Transportation Research Board Special Report 176, p. 12-33.

Varnes, H.D., 1949, Landslide problems of southwestern Colorado: U.S. Geological Survey Circular 31, 13 p.

Wanek, A.A., 1954, Geologic map of the Mesa Verde area, Montezuma County, Colorado: U.S. Geological Survey Oil and Gas Investigation Map OM-152, scale 1: 63,360.

Wanek, A.A., 1959, Geology and fuel resources of the Mesa Verde area, Montezuma and La Plata Counties, Colorado: U.S. Geological Survey Bulletin 1072-M, p. 667-721, pl. 49 , scale 1:63,360. 
Western Regional Climate Center, 2011, Mesa Verde Natl Park (055531): National Oceanic and Atmospheric Administration (NOAA) National Climatic Data Center. Accessed on April 28, 2011, at http://www.wrcc.dri.edu/summary/ Climsmco.html).

Wright, K.L., 2006, The water mysteries of Mesa Verde: Boulder, Colo., Johnson Books, 132 p.

Publishing support provided by:

Denver Publishing Service Center

For more information concerening this publication, contact:

Center Director, USGS Geology and Environmental Change Science Center

Box 25046, Mail Stop 980

Denver, CO 80225

(303) 236-5344

Or visit the Geology and Environmental Change Science Center Web site at: http://esp.cr.usgs.gov/ 


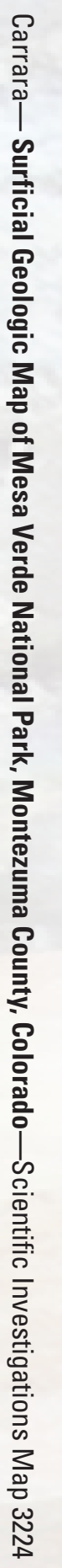

